\title{
Public policy influence on renewable energy investments-A panel data study across OECD countries
}

\author{
Friedemann Polzin ${ }^{\mathrm{a}, \mathrm{b}, *}$, Michael Migendt ${ }^{\mathrm{a}}$, Florian A. Täube ${ }^{\mathrm{c}}$, Paschen von Flotow ${ }^{\mathrm{b}}$ \\ ${ }^{a}$ EBS Business School, Strascheg Institute for Innovation and Entrepreneurship (SIIE), Rheingaustr. 1, 65375 Oestrich-Winkel, Germany \\ ${ }^{\mathrm{b}}$ Sustainable Business Institute (SBI), Zehnthofstr. 1, 65375 Oestrich-Winkel, Germany \\ ${ }^{\mathrm{c}}$ Emile Bernheim Chair of Entrepreneurship in a Global Context, Solvay Brussels School of Economics and Management, Université libre de Bruxelles, Avenue \\ F.D. Roosevelt 42, B-1050 Brussels, Belgium
}

\section{H I G H L I G H T S}

- Panel data study on the effectiveness of policies to induce RE investments.

- Novel combination of datasets (BNEF/IEA) in solar, wind and biomass sectors.

- FIT proves to be more effective than subsidies for less mature technologies.

- RPS and tradable permit systems seem more effective for mature technologies.

- A long-term strategic planning framework is useful to attract institutional investors.

\section{A R T I C L E I N F O}

\section{Article history:}

Received 20 June 2014

Received in revised form

16 January 2015

Accepted 22 January 2015

Available online 11 February 2015

Keywords:

Renewable energy

Public policy mix

Institutional investors

Longitudinal analysis

\begin{abstract}
A B S T R A C T
This paper examines the impact of public policy measures on renewable energy (RE) investments in electricity-generating capacity made by institutional investors. Using a novel combination of datasets and a longitudinal research design, we investigate the influence of different policy measures in a sample of OECD countries to suggest an effective policy mix which could tackle failures in the market for clean energy. The results call for technology-specific policies which take into account actual market conditions and technology maturity. To improve the conditions for institutional investments, advisable policy instruments include economic and fiscal incentives such as feed-in tariffs (FIT), especially for less mature technologies. Additionally, market-based instruments such as greenhouse gas (GHG) emission trading systems for mature technologies should be included. These policy measures directly impact the risk and return structure of RE projects. Supplementing these with regulatory measures such as codes and standards (e.g. RPS) and long-term strategic planning could further strengthen the context for RE investments.
\end{abstract}

(c) 2015 Elsevier Ltd. All rights reserved.

\section{Introduction}

Climate change has been aggravating in recent years as $\mathrm{CO}_{2}$ emissions continue to grow in developed and developing countries alike (IPCC, 2014). OECD countries have a larger responsibility to address climate change, as they accounted for almost $50 \%$ of the global carbon emissions in 2010, most of which were linked to the energy sector (BNEF, 2013; Müller et al., 2011; OECD, 2013). One option for transitioning towards a low-carbon society is to increase

\footnotetext{
* Corresponding author at: Sustainable Business Institute (SBI), Zehnthofstr. 1 65375 Oestrich-Winkel, Germany. Tel.: +496723 9963 19; Fax: +496723996321. E-mail address: polzin@sbi21.de (F. Polzin).
}

the share of energy (especially electrical energy) generated from renewable energy (RE) sources (Foxon and Pearson, 2007; Jefferson, 2008). To complement these activities, it is necessary to also increase overall efficiency of the energy sector (Eichhammer et al., 2013; Marques and Fuinhas, 2011; Schleich, 2009); however throughout this article we focus on capacity additions of RE. Given limited financial resources of state governments, the involvement of private markets and investors is needed (Mathews et al., 2010). Investments in clean energy ${ }^{1}$ projects and infrastructure have been growing in the last decade and total up to a relevant amount.

\footnotetext{
${ }^{1}$ Throughout this paper, we will use renewable energy (RE) and clean energy interchangeably.
} 


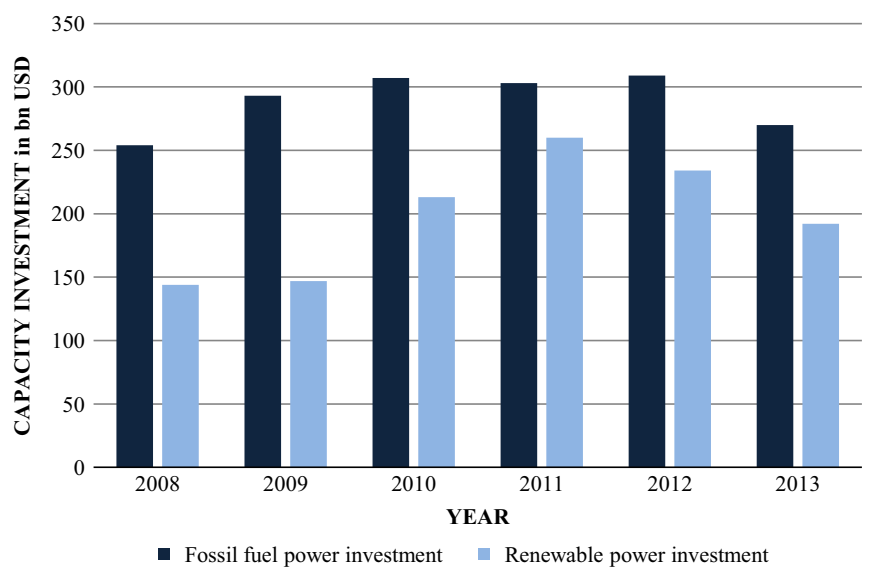

Fig. 1. Renewable power capacity investment compared to fossil-fuel power capacity investment, 2008-2013 in billion USD (Adapted from Frankfurt School-UNEP Centre and BNEF, 2014, p. 31). Renewable energy does not include large hydro. Fossil fuel is gross investment in coal, gas and oil capacity and assumes retired fossil capacity is replaced. However a capacity retirement of $3.3 \%$ per year for coal, $4 \%$ per year for gas and $2.5 \%$ per year for oil is assumed. The numbers in this chart are adjusted for inflation.

Yet the volumes are still smaller than investments in conventional fossil fuel-based power (see Fig. 1) (Frankfurt School-UNEP Centre and BNEF, 2014).

This is partially due to the challenge the diffusion of RE technology represents (Foxon and Pearson, 2007; Friebe et al., 2014, 2013; Veugelers, 2011). Market failures occur related to inherent characteristics of the energy sector which is designed for fossil fuel-based power plants on the one hand, as well as the particular nature of RE technologies on the other (Dinica, 2006; Helm, 2002; Jefferson, 2008; Wüstenhagen and Menichetti, 2012). Long payback periods and illiquid assets coupled with high regulatory dependencies and corresponding uncertainties often make RE unattractive or even unsuitable for investors. While this holds also true for mature technologies and conventional power plants, REs in addition face some technological uncertainty (Kenney and Hargadon, 2012; Mathews et al., 2010).

To mitigate market failures and to compensate for technological and economic weaknesses, policy makers were historically confronted with a variety of options to stimulate diffusion of RE. This article attempts to uncover the effects of different policies to support clean energy applications. It adds to recent academic and political discussions about the choice among feed-in tariffs (FITs) and alternative mechanisms as well as the corresponding overall effectiveness and efficiency of these policy instruments (Carley, 2009; Lesser and Su, 2008; Mathews et al., 2010). However quantitative analyses of the influence of public policies on investments in RE by private institutional investors (i.e. investment and pension funds, banks and insurance companies) are scarce, with longitudinal, let alone panel data analyses almost non-existent (Bolkesjø et al., 2014; Chassot et al., 2014; Lüthi and Prässler, 2011; Lüthi and Wüstenhagen, 2012). This is even more relevant because private institutional investors provide a significant amount of the funds deployed, particularly in certain more mature technologies such as wind (BNEF, 2013; IEA, 2013).

Thus, building on previous work on RE investor behaviour (Bergek et al., 2013; Chassot et al., 2014; Lüthi and Prässler, 2011; Wüstenhagen and Menichetti, 2012), we investigate the influence of public policies on subsequent RE investments by institutional investors across OECD countries over a time period of 12 years (2000-2011). Using a novel dataset gathered from Bloomberg New Energy Finance (BNEF) and the International Energy Agency (IEA) together with the International Renewable Energy Agency (IRENA), this paper applies a panel data regression. We develop policy implications adding to the academic literature of RE policies and RE investment decisions. The overarching research question is: Which policies have proven (most) conducive to investments in renewable energy assets?

The remainder of this paper is structured as follows: Section 2 briefly describes the conceptual motivation. Section 3 introduces the analytical method and data used. Section 4 presents the results and discussion while section 5 finalises with conclusion, limitations and next steps in the research process.

\section{Theoretical background}

\subsection{Public policy influence on renewable energy deployment}

Literature on energy policy has analysed the relationship between policy and RE deployment in a number of different ways, generating evidence for policy makers to support their decisions (Delmas and Montes-Sancho, 2011; Harmelink et al., 2006; Jacobsson et al., 2009; Menz and Vachon, 2006). Fundamental questions such as influence of price or quantity-based mechanisms have been addressed (Menanteau et al., 2003). Prior research thus provides a differentiated picture to support RE deployment.

First of all, fiscal and financial incentives can be provided to accelerate the development of RE projects. A number of scholars (Bolkesjø et al., 2014; Couture and Gagnon, 2010; De Jager et al., 2011; del Río and Bleda, 2012; Jenner et al., 2013; Lesser and Su, 2008; Mitchell et al., 2006) underline the superiority of feed-in tariffs (FIT) to spur deployment and technological diversity and lower risks for private actors associated with RE technologies. The implementation of FIT and changes to the remuneration system may harm the positive effects as seen for example in Spain. These positive effects hold when comparing FIT with other remuneration models such as quotas or auction-based systems (Butler and Neuhoff, 2008; Mitchell et al., 2006). However, del Río and Bleda (2012) argue that a variety of policies consisting of specific and technology-neutral measures provide the most fertile ground for RE technology deployment.

To provide short term fiscal relief for RE projects grants and subsidies can be provided. In the logic of financing innovation this type of support instrument proves especially relevant in the early stages of technology development (Olmos et al., 2012); however it also reduces investors overall cost for RE projects (Bergek et al., 2013; De Jager et al., 2011; Olmos et al., 2012).

Similarly, government loans or loan guarantees could be of interest to private actors as the ability to refinance their activities is crucial for a long-term commitment in RE (Bergek et al., 2013; De Jager et al., 2011, 2008). A growing stream of literature has further analysed the impact of tax-based incentives to spur RE deployment (Barradale, 2010; Bird et al., 2005; Cansino et al., 2010; Quirion, 2010). However, Barradale (2010) highlights the missing policy commitment (due to direct dependency on the public budget) as a main shortcoming of taxes and rebates.

Second, scholars argue that in the sense of carbon and energy market liberalisation preference should be given to market-based instruments as first best solutions, e.g. carbon cap and trading systems (Helm, 2002; Rogge et al., 2011; Rogge and Hoffmann, 2010; Smith and Swierzbinski, 2007). Another market-based system, i.e. the tradability of RE certificates (green certificates) might further spur the deployment of renewables (Jensen and Skytte, 2002; Szabó and Jäger-Waldau, 2008).

Third, policy makers have the option to provide funds to local authorities to be spent on RE deployment (i.e. funds to subnational governments) (Bird et al., 2005; De Jager et al., 2008; Menz and Vachon, 2006; Ragwitz et al., 2008) or directly invest in complementary assets such as infrastructure (De Jager et al., 2011, 
2008; Henriot, 2013; Steinbach, 2013).

Fourth, investment decisions can be related to policy instruments that do not directly impact the risk and return structure of RE projects. For example, the perception of investment opportunities and preference for short term or long-term incentives also influence the decision to invest (Masini and Menichetti, 2012). Prior literature has found that the creation of the surrounding institutions is a major driver to facilitate investments in RE technologies (Bergek et al., 2013; Wüstenhagen and Menichetti, 2012). This could be accompanied by a long-term strategic framework which is valued by institutional investors as they prefer stability in cash flows over the duration of their investments (De Jager et al., 2011, 2008; Lüthi and Wüstenhagen, 2012), thus foreseeable changes to regulations and policy consistency are paramount (White et al., 2013).

Finally, regulatory measures to stimulate markets need to be established even though diffusion and application of RE technologies is socially and politically desirable (Jefferson, 2008). Furthermore, the highly regulated environment for diffusion of mature REs might require new forms of regulation compared to the commercialisation of RE in order to overcome market failures and dissolve path dependencies. Research has on the one hand highlighted mixed effects of renewable portfolio standards (RPS) for the US (Delmas and Montes-Sancho, 2011; Carley, 2009; Bird et al., 2005). Carley (2009), Bird et al. (2005) and Menz and Vachon (2006) show that RPS systems increase the share of RE produced but not the absolute amount, whereas Delmas and Montes-Sancho (2011) do not find a significant effect on RE capacity. On the other hand, further mandatory requirements, quota, and obligation schemes do exhibit a positive influence on RE application (Menz and Vachon, 2006); however, they have proven inferior to other instruments such as FIT (Butler and Neuhoff, 2008; De Jager et al., 2011, 2008; Mitchell et al., 2006).

One solution to address the problems encountered so far, apparently, is a 'policy mix' consisting of complementary instruments. However, no scholarly consensus exists on what the optimal policy mix could look like (Foxon and Pearson, 2007) or on which criteria should be applied to determine it (Carley, 2009). For example, Del Rio and Bleda (2012) argue that a variety of policies, consisting of technology-specific and technology-neutral measures is needed to enhance deployment of RE technologies.

Following this debate scholars applied quantitative statistical methods (i.e. panel data analysis on country level) to investigate policy impacts on RE deployment. For example, Johnstone et al. (2010) found that market based approaches favour technologies that are close to be technologically and cost wise competitive with fossil fuels (such as wind) whereas feed-in tariffs are conducive to innovation in less mature technologies (such as solar). On the other hand, Popp et al. (2011) do not find a significant effect of either FIT or a renewable certificate system on wind power investments.

Building on this work, scholars tried to uncover the influence of a number of different policy instruments on the contribution of renewables to the total energy supply (Marques and Fuinhas, 2012a). They show that aggregated measures such as fiscal and financial incentives (including FIT) as well as measures, that seek to define strategies and outline specific programs to promote these RE sources, have a positive significant impact. Controlling for a range of political elements such as energy security, Kyoto protocol ratification and socio-economic factors (e.g. prices for fossil-fuels, welfare) Aguirre and Ibikunle (2014) found no significant positive influence of policies on RE growth, however they found a negative contribution of fiscal and financial incentives (i.e. taxes).

In sum, the literature has been searching for an integral overview of sustainable energy policy to spur RE diffusion. Given the mixed results of prior findings, we add to this debate through our research which aims at uncovering the effectiveness of different disaggregated policy instruments (i.e. the optimal policy mix) to induce private finance in RE assets. More specifically, we contribute to two different discussions: The FIT versus other support scheme debate, and the overall assessment of different support mechanisms for RE.

Beyond economic, regulatory and behavioural barriers, institutional factors such as acceptance among the local communities hinder the deployment of RE technologies (Arabatzis and Myronidis, 2011; Tampakis et al., 2013; Wüstenhagen et al., 2007). With our analysis we contribute to the private sector perspective on RE investments, leaving aside potential negative externalities caused by technologies deployed (Friebe et al., 2014).

\subsection{Investors' perspective on renewable energies}

The question of how to effectively mobilise financial resources for the deployment of RE (RE projects) and complementary infrastructure has been a major concern both in the academic and political debate (Bergek et al., 2013; De Jager et al., 2011; Mathews et al., 2010; Mowery et al., 2010; Veugelers, 2011; Wüstenhagen and Menichetti, 2012). Mathews et al. (2010, p. 3263) note that 'the issue of public vs. private financing is not yet adequately explored', but add that there is consensus among policy makers that the transition to a low carbon economy will not happen without the involvement of private institutional investors (Müller et al., 2011; Popp et al., 2011).

Investments in RE deployment by institutional investors (i.e. investment/pension funds, banks and insurance companies) are typically hindered by a number of factors; high upfront costs, risks, and uncertainty regarding long-term viability of the technology, long payback periods, high regulatory and infrastructural dependency as well as public acceptance (Cárdenas-Rodríguez et al., 2013; De Jager et al., 2011; Haley and Schuler, 2011; Kenney and Hargadon, 2012; Müller et al., 2011). These factors directly influence the risk/return profile of an RE investment, which is a major determinant for institutional investors (Cárdenas-Rodríguez et al., 2013; Dinica, 2006).

The ultimate requirement for a sustainable RE policy is a reduction of capital costs to create a level playing field with fossil fuel-based technologies which have been heavily subsidised in the past (Szabó and Jäger-Waldau, 2008). To lower these costs properly, policy makers have to take into the account factors that influence institutional investors. Scholars analysed the decision criteria for investors. Bergek et al. (2013) suggest evaluation criteria such as (overall or portfolio) cost, perceived (market) uncertainty and political risk. Based on insights from project developers, regulatory risks and the streamlining of the administrative process (grid access) have been identified as relevant decision criteria (Friebe et al., 2014; Lüthi and Prässler, 2011; Lüthi and Wüstenhagen, 2012). Chassot et al. (2014) confirm these propositions by highlighting the perceived risk caused by policies as the main determinant of investment decisions.

Szabó and Jäger-Waldau (2008) suggest that a more competitive financial environment could actually reduce the costs of capital for RE projects, given that capital markets function efficiently. Therefore, a combination of supportive financial regulation and transparent policy making would be conducive to institutional investors to compete for building RE capacities (Bergek et al., 2013; Lüthi and Wüstenhagen, 2012; Wüstenhagen and Menichetti, 2012). This environment would in turn lower the perceived regulatory risk and, thus, lower the financing costs for RE projects while still allowing reasonable rates of return. Decreasing support corresponding to technological development, meaning adaptive policy making, can furthermore spur the deployment of more innovative technologies (Szabó and Jäger-Waldau, 2008). 
With our analysis we explore which policy instruments have been conducive to RE investments by institutional investors, thus we examine this relationship over time. We answer the call for research of Wüstenhagen and Menichetti (2012) by specifically investigating the influence of policy on the perception of institutional investors.

\section{Methods and data}

\subsection{Research design}

Investigating the diffusion of a particular technology and corresponding investments requires a longitudinal research design (Angrist and Pischke, 2008; Cárdenas-Rodríguez et al., 2013; Johnstone et al., 2010; Popp et al., 2011; Wooldridge et al., 2009). Prior literature applied panel data regressions at the EU level (Bolkesjø et al., 2014; Marques and Fuinhas, 2012a) with a few comparing OECD or BRIC countries (Aguirre and Ibikunle, 2014; Cárdenas-Rodríguez et al., 2013; Johnstone et al., 2010; Popp et al., 2011).

Building on these methodological approaches we cover a variety of OECD countries, conducting a panel data regression throughout the time period from 2000 to 2011 to explain the influence of policy instruments on the diffusion of clean energy technologies. As policy instruments do not exhibit an immediate effect on technology application and investments, we add a lag procedure which is explained in Section 3.3.4 (Wooldridge et al., 2009). The time frame is chosen due to the limited availability of high quality data, and as it still covers the most substantial developments in the worldwide renewable energy sector, especially regarding the involvement of institutional investors. ${ }^{2}$ Globally the wind sector grew from 18 GW installed capacity in 2000 to 238 GW installed capacity in 2011, while the solar sector grew from $1.5 \mathrm{GW}$ installed capacity in 2000 to $67 \mathrm{GW}$ installed capacity in 2011 (IEA, 2014). The biomass sector, at the same time, grew from $38 \mathrm{GW}$ installed capacity in 2000 to $74 \mathrm{GW}$ installed capacity in 2011 (NREL, 2013).

\subsection{Data}

Data was collected from two independent data sources. Investments (additions in RE capacity) have been drawn from BNEF, which possesses one of the most comprehensive databases in the field of clean technology financing (Cárdenas-Rodríguez et al., 2013). It contains information on installed electricity generating capacity, date, transaction type, financing type, amount of equity, and amount of debt. We used data from 2003 to 2011. The complete database includes 5840 Solar Investments, 9643 Wind Investments and 2889 Biomass \& Waste Investments. These three RE subsectors account for $72 \%$ of the RE funds invested and with $74 \mathrm{GW}$ installed for $75 \%$ of all capacity additions in the period, and have therefore been selected for further analysis. The records of the BNEF database start with the year 2003 and we further decided to use the data up to the year 2011, as data quality of the following year did not meet the standards of previous years at the time of research in early 2013.

Policy indicators were drawn from the IEA/IRENA Policy and Measures (PM) database which includes policy measures in OECD countries from 1974 onwards. These indicators have been used by scholars to analyse the impacts of aggregated policy instruments

\footnotetext{
${ }^{2}$ When using data from BNEF, one has to be aware of the fact that the data is being updated after a certain year. Thus we have chosen to limit the data of the dependent variable to 2011, as this timeframe covers the most reliable data quality.
}

in Europe (Cárdenas-Rodríguez et al., 2013; Marques and Fuinhas, 2012a, 2012b) and globally (Aguirre and Ibikunle, 2014). We used the IEA/IRENA policy measures data from 2000-2011 which corresponds to the availability of investment data. The database includes a total of 957 distinct policy measures active in the respective years resulting in 7835 policy data points (see Appendix A2).

We structured the data according to sectors (Multiple RE sources, Wind, Solar, and Biomass) and applied additional data processing: First, we removed cases with missing values and included only completed deals. Second, our interest in the influence of policy measures lead to the exclusion of countries with less than three consecutive years of investor activities. The case-selection is carried out for each sector analysed (see Section 3.3. for the procedure and Table A1 for a list of countries in the subsamples). The selection of policy instruments included in the model is described in Section 3.3.2.

As control variables we further included macroeconomic and energy market data from the US Energy Administration-EIA (carbon intensity of the economy), OECD (long-term interest rates, share prices) and from the World Bank (total energy consumption, gross domestic product (GDP)) in our analysis.

\subsection{Model}

We investigate the influence of the set of different policy measures on subsequent investments into RE capacity by institutional investors. The components of this model are shown in Fig. 2. The five different subsets of policies include 957 different (countries and time series generated) measures of which some are active in every sector, while some are active in a single sector only. The included variables are log-transformed to correct for the skewed distribution of both dependent and independent variables (Hair, 2010). We expect to see a positive influence for every subset of policies on the capacity additions (see Fig. 2).

\subsubsection{Dependent variable (DV)}

The dependent variable, drawn from BNEF, for the overall model is measured as aggregated newly installed capacity (in MW) in a certain country and year in a specific subsector (e.g. solar, wind, biomass). We use capacity indicators as they represent the most accurate proxy for the deployment of a technology (Popp et al., 2011).

\subsubsection{Independent variables (IV)}

The main independent variables were drawn from the IEA/IRENA database. We constructed our indicators by counting distinct policies per country per year (see Table A2 for a complete categorisation). They are measured by the number of active instances of policies affecting the RE sector (Johnstone et al., 2010; Marques and Fuinhas, 2012a). We call these counts 'accumulated number of RE policies and measures' (ANPM) (Aguirre and Ibikunle, 2014). The active policy instances are used as an ordinal variable with the assumption that the more policies (of a kind) the better for investments. This allows comparing the experience of many countries and decomposing the effect of distinct factors econometrically (Cárdenas-Rodríguez et al., 2013).

We can further distinguish between technology specific instruments (e.g. specific targets for certain energy sources) and instruments that apply to all types of RE (e.g. German FIT). The IEA/IRENA PM database provides relevant information on characteristics (title, country, year (started and ended), policy status (e.g. in force, ended, superseded), policy type, policy target (e.g. subsector such as solar, wind and biomass), geographical scope (supranational, national, regional), policy sector (e.g. electricity, multi-sectoral, framework policy), size of plant targeted (large, 


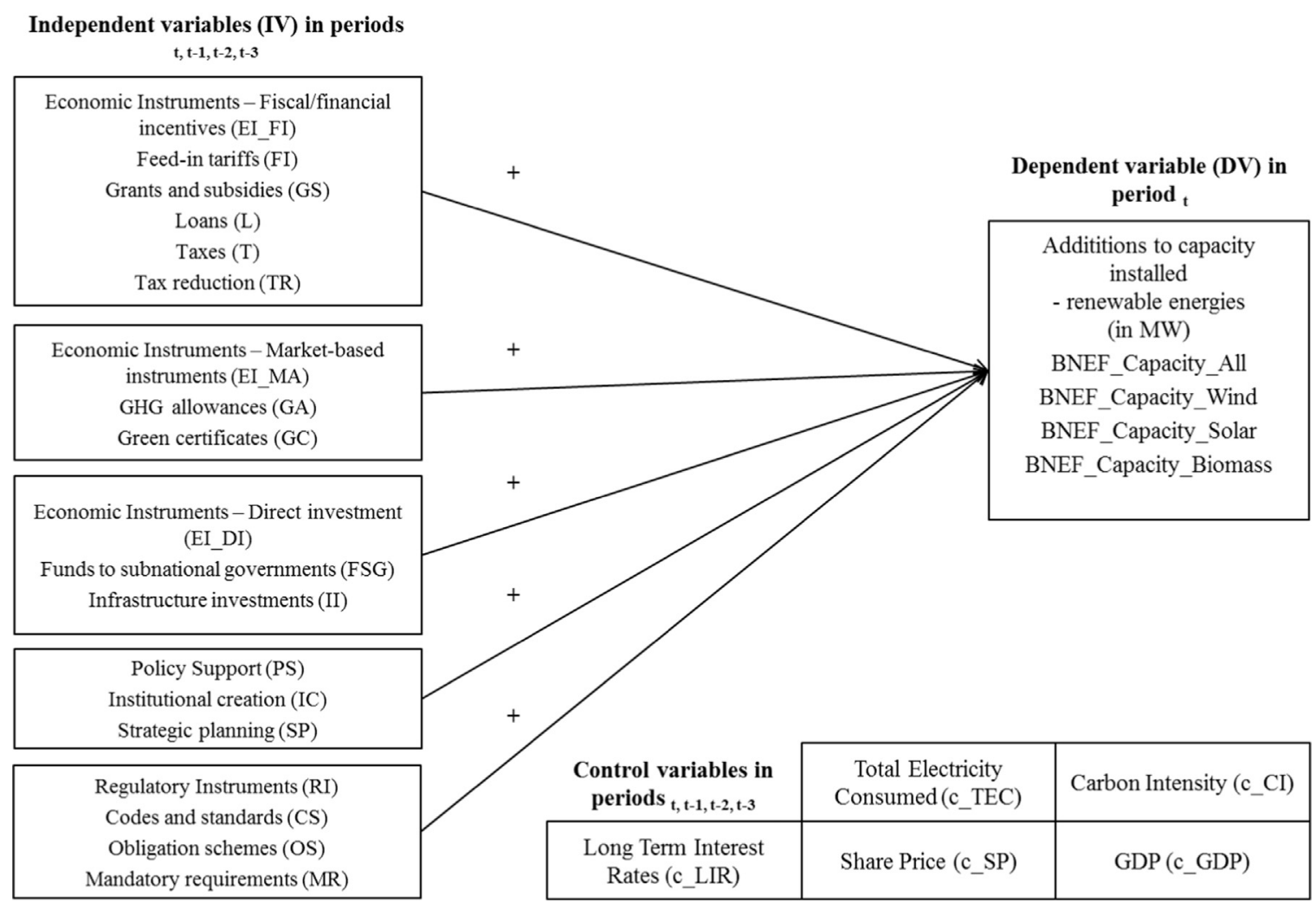

Fig. 2. Model for the quantitative panel regression.

small or both) and funding (partially, depending on instrument)). We build our model with distinct policies as independent variables based on prior literature reviewed in Section 2.

\subsubsection{Controls}

To account for technological progress, economies of scale as well as the fact that the installed capacity gains momentum (leading to variance from the previous years), we include year and country dummy variables. To rule out alternative explanation for RE investments we included a number of control variables in the regressions. Economies of scale are picked up by the time dummy variable and therefore not included among the control variables. Further economic indicators that might drive capacity additions include the GDP (c_GDP). To account for differences in energy use and consumption we include energy dependency $\left(\mathrm{CO}_{2}\right.$ intensityMetric Tons of Carbon Dioxide per thousand year 2005 U.S. dollars GDP) as well as electricity consumption in the regression (c_CI, c_TEC). Finally, to account for factors influencing investor behaviour, we include interest rates (c_LIR) as well as share prices (c_SP) of local indices as these might render an investment into RE vs. non-RE more or less attractive.

\subsubsection{Lag structure}

As common for longitudinal analyses we assume that the independent variable affects the dependent variable immediately and with a certain delay. This relation is included in our model through a lag structure where we compare the respective time values of the DV with several different time values of the IV. This approach helps in this case to account for the time-dependent influence of policy measures on investor behaviour (Angrist and Pischke, 2008; Wooldridge et al., 2009). We decided to introduce a lag structure with a lag of the policy effectiveness within zero to three years (i.e. investments in capacity in year ${ }_{t}$ are influenced by policy measures in years $t, t-1, t-2, t-3)$. This means policies could have a direct effect on investor decisions or it could take up to three years for a policy to trigger a capacity addition. On the one hand, it is possible that investors anticipate the regulation and already have their projects ready when it is passed, as the regulatory process is mostly open. On the other hand, there are factors delaying the investment process such as the time needed to build the wind farm or solar park and to gain access to the grid. In general, changes in regulations evolve throughout time and are communicated prior to them being passed and set active.

\subsection{Longitudinal analysis (panel data regression)}

Prior research acknowledges that determining the influence of policy measures on investments in RE capacity is challenging since spatial and temporal effects could overlap (Marques et al., 2010; Marques and Fuinhas, 2012a). Following their work we assume panel auto-correlation and contemporaneous correlations as similarities in policy design (e.g. in EU countries) and a tendency to increase the number of policy measures which can be observed throughout the data. The literature reviewed in Section 2 analyses policy measures that are conducive to RE investments, which are included in the model (see Section 3.3.2). The best fitting econometric technique is to use a panel data approach under the conditions resulting from characteristics of policy making (Marques and Fuinhas, 2012a).

We estimate panel corrected standard error (PCSE), ordinary least squares (OLS) and random effects estimator (REE) models. Following Marques and Fuinhas (2012a) and to mitigate errors resulting from the data structure, we use several econometric treatments: heteroskedasticity, panel autocorrelation, and contemporaneous correlation are addressed through fitting approaches (Reed and Ye, 2011). Thus, we circumvent inefficient coefficient estimation and a biased estimation of standard errors (Marques and Fuinhas, 2012a). We do not focus on OLS or REE as 
Table 1

Specification tests for the quantitative model.

\begin{tabular}{|c|c|c|c|c|c|c|c|c|}
\hline & \multicolumn{4}{|c|}{ Random effects/Pooled OLS } & \multicolumn{4}{|l|}{ Fixed effects } \\
\hline & Multiple RE & Solar & Wind & Biomass & Multiple RE & Solar & Wind & Biomass \\
\hline Modified Wald test & - & - & - & - & $236.84^{* * * * *}$ & $91.24^{* * * *}$ & $1052.72^{* * * *}$ & $141.05^{* * *}$ \\
\hline Wooldridge test $F(N(0,1))$ & $19.20^{* * * *}(\mathrm{OLS})$ & $12.63^{* * * *}(\mathrm{OLS})$ & $19.62^{* * *}(\mathrm{OLS})$ & 1.22 (OLS) & - & - & - & - \\
\hline Pesaran's test & $19.55^{* * * *}$ & $5.54^{* * * *}$ & $16.26^{* * * *}$ & $8.70 * * *$ & $15.02^{* * * *}$ & $4.13^{* * * *}$ & $10.15^{* * * *}$ & $4.61^{* * * *}$ \\
\hline Frees' test & $3.00^{* * * *}$ & $1.03^{* * *}$ & $2.49^{* * * * *}$ & $0.90^{* * * * *}$ & $2.34^{* * * * *}$ & 0.22 & $1.87^{* * * *}$ & $0.63^{* *}$ \\
\hline Friedman's test & $78.00^{* * * *}$ & $30.63^{* * * *}$ & $63.77^{* * * *}$ & $38.51^{* * * *}$ & $25.35^{* * *}$ & & $45.38^{* *}$ & $27.18^{*}$ \\
\hline
\end{tabular}

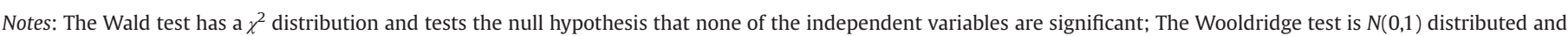

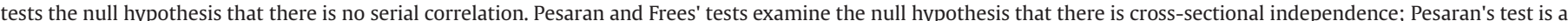

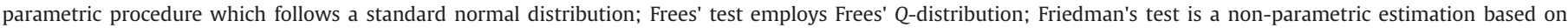

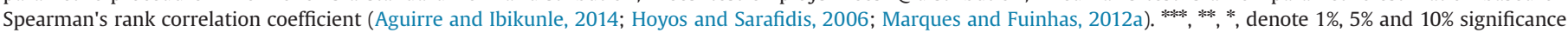
level, respectively. xtcsd and xtserial commands were used.

they do not address serial correlation and contemporaneous correlation, however, we include the estimates for reasons of robustness (Marques and Fuinhas, 2012a, 2012b).

Our analysis proceeds as suggested by Marques and Fuinhas (2012a): (1) We observe the quality and nature of the data. (2) We test the presence of heteroskedasticity, panel autocorrelation and contemporaneous correlation. (3) If the results do not conform to standard assumptions about errors (i.e. if the error terms are independent and identically distributed-iid), we employ the PCSE estimator, which is a suitable solution to improve the accuracy of the estimators. (4) We compare the results with those derived from OLS and REE to check the robustness.

Table 1 presents results from the estimations of the specification tests regarding quality and nature of the data and confirms that especially the policy data is heteroskedastic (i.e. has a common variance) and that panel autocorrelation and contemporaneous correlation is present. Hence we use PCSE estimator as main econometric analysis technique.

As public policy effects differ across RE subsectors (e.g. solar, wind, biomass) we carried out the further analysis sector by sector and also aggregated the data (Multiple RE sources) to analyse effects that are similar across sectors. Thereby, we can also distinguish policy instruments between the sectors as well as policies that apply to all sectors.

Panel data estimation without lag procedure (I)

$\mathrm{IC}_{j k}=$ const $+\sum_{i=1}^{i} \beta_{i} P M_{i j k}+C_{j k}+d_{j}+d_{k}+\varepsilon_{j k}$

Panel data estimation with lag procedure (II-IV)

$\mathrm{IC}_{j k}=$ const $+\sum_{i=1}^{i} \beta_{i} P M_{i j k-l}+C_{j k-l}+d_{j}+d_{k-l}+\varepsilon_{j k-l}$

$I C_{j k}$ is the aggregated installed capacity financed by institutional investors per country j per year k. $P M_{i j k}$ is a vector of i explanatory variables representing policy measures based on the IEA/IRENA scheme (per country per year). $C_{j k}$ consists of a number of control variables (Model I). For the analyses of time-dependent phenomenon we include lags $l$ of one to three years in the regressions (Model II-IV). The dummy variables $d_{j}$ and $d_{k}$ refer to country and time, respectively. The PCSE estimator permits the error term $\varepsilon_{j k}$ to be correlated over the cases (i.e. countries). Moreover a first-order autoregression for $\varepsilon_{j k}$ over time can be used. Finally the estimator allows $\varepsilon_{j k}$ to be heteroskedastic (Cameron and Trivedi, 2009; Marques and Fuinhas, 2012a).

\section{Results and discussion}

The aim of our research is to uncover the influence of different policy instruments on subsequent investments in RE by private institutional investors over time in a longitudinal research design. Policy makers interested in improving their country's transition towards RE should implement measures for attracting private institutional investors, as the capital required for large-scale RE projects by far surpasses the available funds of utility companies as well as the public budgets. Institutional investors' capital played an important role in the development of the RE sector, and establishing a favourable environment for them, including specific policies, should increase capacity additions in the future. With our analysis we provide an integral picture of RE policies and their influence on RE capacity investments by institutional investors. We intend to contribute to the literature surrounding investor behaviour regarding $\mathrm{RE}$ technologies, as investors provide funds for large scale deployment (Bergek et al., 2013; Lüthi and Prässler, 2011; Wüstenhagen and Menichetti, 2012).

The analysis is conducted on a sectoral basis to allow differentiated policy recommendations. In the following discussion, we highlight significant effective and ineffective policy measures and relate our results to previous studies in this literature stream (Aguirre and Ibikunle, 2014; Marques et al., 2010; Marques and Fuinhas, 2012a).

Table A2 shows the descriptive statistics of our analysis. The correlation among explanatory variables has been subject to analysis as well. The simultaneous use of several drivers leads to the hypothesis of collinearity among explanatory variables. Tables A2 and A3 show the summary statistics and the correlation coefficients for our analysis. The analysis suggests the absence of collinearity among the exogenous (independent) variables.

We estimated all models separately using the PCSE and the OLS estimator as well as REE for robustness checks. We conducted the analysis for Multiple RE data and distinct sectors. The estimation results are displayed in order of the categories and different policy measures. We report the results with models based on a time lag of 1 year, thus, investments lagging behind the introduction of policy by 1 period. With this analysis we go beyond extant work (Aguirre and Ibikunle, 2014; Johnstone et al., 2010; Marques and Fuinhas, 2012a), ruling out reverse causality (i.e. investments driving policies for example through lobbying) and providing a more realistic approach to renewable deployment, taking into account a lagging reaction of investors to policy measures. The results of our complete policy variable analysis are presented in Tables 2 and 3. An overview about our results can be drawn from Table 4.

\subsection{Fiscal and financial incentives}

First of all, our results highlight the effectiveness of FIT to spur capacity additions which directly impact the risk and return structure of RE projects as a policy instrument that guarantees a 
Table 2

Panel-corrected standard errors (PCSE) regression results.

\begin{tabular}{|c|c|c|c|c|c|c|c|c|}
\hline \multirow[t]{3}{*}{ Independent variables (ANPM) $(t-1)$} & \multicolumn{8}{|l|}{ PCSE } \\
\hline & \multicolumn{2}{|c|}{$\begin{array}{l}\text { No autocorrelation } \\
\text { Multiple RE } \\
\text { (I) }\end{array}$} & \multicolumn{2}{|c|}{$\begin{array}{l}\text { No autocorrelation } \\
\text { Wind } \\
\text { (II) }\end{array}$} & \multicolumn{2}{|c|}{$\begin{array}{l}\text { No autocorrelation } \\
\text { Solar } \\
\text { (III) }\end{array}$} & \multicolumn{2}{|c|}{$\begin{array}{l}\text { No autocorrelation } \\
\text { Biomass } \\
\text { (IV) }\end{array}$} \\
\hline & Coeff. & S.E. & Coeff. & S.E. & Coeff. & S.E. & Coeff. & S.E. \\
\hline EI_FI_FI ${ }_{j k}$ & $0.69^{* * * *}$ & 0.28 & $0.70^{* * * *}$ & 0.26 & $1.18^{* * *}$ & 0.26 & 0.09 & 0.24 \\
\hline EI_FI_GS ${ }_{j k}$ & 0.33 & 0.25 & 0.13 & 0.24 & $0.61^{* * * *}$ & 0.23 & $0.61^{* *}$ & 0.24 \\
\hline EI_FI_L $\mathrm{L}_{\mathrm{jk}}$ & -0.36 & 0.26 & 0.30 & 0.27 & $-0.91^{* * *}$ & 0.30 & -0.16 & 0.32 \\
\hline EI_FI_TR ${ }_{\mathrm{jk}}$ & $0.40^{* * *}$ & 0.18 & 0.20 & 0.20 & -0.01 & 0.28 & 0.10 & 0.18 \\
\hline EI_FI_T ${ }_{j k}$ & $-0.90^{*}$ & 0.48 & -0.51 & 0.34 & $1.00^{* * * *}$ & 0.45 & -0.20 & 0.29 \\
\hline EI_MI_GA $A_{j k}$ & $1.48^{* * *}$ & 0.62 & $1.59 * * * *$ & 0.41 & $-1.17^{* * *}$ & 0.60 & $0.97 *$ & 0.47 \\
\hline EI_MI_GC & -0.02 & 0.34 & -0.03 & 0.35 & $-2.27^{* * * *}$ & 0.41 & 0.06 & 0.34 \\
\hline EI_DI_FSG ${ }_{j k}$ & $-0.65^{*}$ & 0.40 & -0.38 & 0.43 & $-1.43^{* * * *}$ & 0.45 & $1.50^{* * * * k}$ & 0.39 \\
\hline EI_DI_II ${ }_{\mathrm{jk}}$ & 0.15 & 0.26 & 0.37 & 0.24 & 0.21 & 0.40 & $-1.20^{* * *}$ & 0.39 \\
\hline PS_IC $\mathrm{jk}_{\mathrm{jk}}$ & -0.41 & 0.28 & 0.13 & 0.26 & $-1.51^{* * * *}$ & 0.38 & $0.83^{* * *}$ & 0.37 \\
\hline PS_SP ${ }_{j k}$ & $0.70^{*}$ & 0.37 & 0.16 & 0.43 & $2.35^{* * * k *}$ & 0.30 & $-0.44^{*}$ & 0.24 \\
\hline RI_CS ${ }_{\mathrm{jk}}$ & $0.45^{* * * *}$ & 0.17 & $0.63^{* * *}$ & 0.19 & $0.54^{* *}$ & 0.27 & -0.41 & 0.37 \\
\hline RI_OS ${ }_{j k}$ & 0.28 & 0.26 & -0.09 & 0.31 & 0.16 & 0.31 & -0.01 & 0.27 \\
\hline RI_MR ${ }_{\mathrm{jk}}$ & 0.52 & 0.36 & 0.21 & 0.32 & $0.77^{* * *}$ & 0.37 & 0.28 & 0.27 \\
\hline \multicolumn{9}{|l|}{ Control variables } \\
\hline$c_{-} \mathrm{TEC}_{\mathrm{jk}}$ & 0.64 & 0.22 & $0.75^{* * *}$ & 0.36 & 0.95 & 0.74 & $-1.97^{* * * *}$ & 0.65 \\
\hline c_Cl $\mathrm{Cl}_{\mathrm{jk}}$ & -0.09 & 0.67 & $1.94^{* * *}$ & 0.94 & $-6.01 * * *$ & 2.24 & $4.37^{* * * *}$ & 1.56 \\
\hline$c_{-} L_{I R}{ }_{\mathrm{jk}}$ & $-0.67^{* * * *}$ & 0.19 & $-0.66^{* * * *}$ & 0.19 & -0.54 & 0.75 & $-0.57^{* *}$ & 0.29 \\
\hline c_SP $\mathrm{jk}_{\mathrm{jk}}$ & $1.84^{* * * * *}$ & 0.56 & $1.58 * * *$ & 0.62 & -0.24 & 0.59 & 0.61 & 0.42 \\
\hline c_GDP $P_{j k}$ & -0.02 & 0.08 & -0.06 & 0.08 & -0.82 & 0.70 & $2.16^{* * * *}$ & 0.58 \\
\hline _cons & $-7.12^{* * *}$ & 3.29 & $-6.74^{* *}$ & 3.47 & 21.59 & 17.18 & $-53.24^{* * * *}$ & 13.25 \\
\hline Observations & \multicolumn{2}{|l|}{330} & \multicolumn{2}{|l|}{319} & \multicolumn{2}{|l|}{176} & \multicolumn{2}{|l|}{220} \\
\hline$R^{2}$ & \multicolumn{2}{|l|}{0.38} & \multicolumn{2}{|l|}{0.40} & \multicolumn{2}{|l|}{0.49} & \multicolumn{2}{|l|}{0.38} \\
\hline Wald & \multicolumn{2}{|l|}{$258.81^{\text {****** }}$} & \multicolumn{2}{|l|}{$208.87^{* * * * *}$} & \multicolumn{2}{|l|}{$161.69^{* * * *}$} & \multicolumn{2}{|l|}{$169.40^{* * * *}$} \\
\hline
\end{tabular}

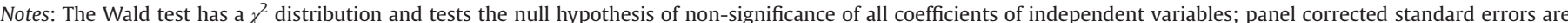

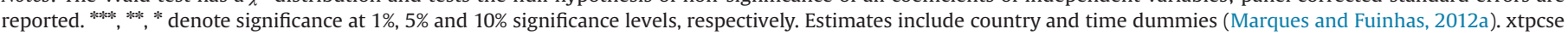
command was used.

certain return on investment and provides an incentive for investors. FIT have been implemented in a range of countries, starting with Germany and Austria in 2000. The aggregated results (Multiple RE) as well as wind and solar sector results revealed a highly significant positive coefficient. However, the effect differs across sectors. Whereas in the solar sector FIT has a stronger impact than overall, FIT is less effective in the wind sector.

FITs proved particularly successful in countries such as Germany and Italy with some exceptions in other countries (e.g. Spain) (Bolkesjø et al., 2014; Couture and Gagnon, 2010; del Río and Bleda, 2012; Jenner et al., 2013; Lesser and Su, 2008; Mitchell et al., 2006). This instrument is a strong signal to investors as it addresses the capital market restrictions by adjusting the risk/return structure (Cárdenas-Rodríguez et al., 2013). Thus our research is in line with evidence by del Río and Bleda (2012) who underline the superiority of FITs to spur deployment and to lower risks associated with RE technologies. In addition our research confirms that a variety of policies consisting of specific and technologyneutral measures spur RE technology deployment.

Second, our results show that grants and subsidies prove to be effective as short term measures to alleviate finance constraints. This holds true for the solar and biomass sectors. Grants and subsidies temporally reduce the cost of finance for a project, and directly depend on a public budget (Johnstone et al., 2010) which makes them more unstable than for example FIT. This is shown by our results of the solar sector. Institutional investors exhibit a preference of FIT over subsidies. With this analysis we confirm earlier work, that highlighted this type of support instrument can also contribute during the diffusion stages of the innovation cycle (Bergek et al., 2013; Bolkesjø et al., 2014; Olmos et al., 2012).

Third, we provide evidence for the effectiveness of loans and loan guarantee programs. According to our results this type of instrument does not spur the deployment in the solar sector. This stands in contrast to prior literature which showed that loans and loan guarantees could enhance institutional investors ability to refinance by reducing cost of capital (Bergek et al., 2013; De Jager et al., 2011, 2008).

Our research regarding tax-based measures revealed mixed evidence. On the one hand aggregated results point towards a negative effect of taxes on subsequent capacity additions in renewables; however results from the solar sector reveal a positive impact. On the other hand, tax reductions tend to increase overall capacity in renewables, with no particular effect in the sectors. We therefore confirm earlier research that pointed towards an ambivalent nature of taxes as they depend on public budgets (Barradale, 2010; Cansino et al., 2010; Quirion, 2010).

Above all we confirm Marques and Fuinhas, (2012a) who found that fiscal and financial incentives are conducive to increasing the share of RE. We extend their results by decomposing the indicator into distinct policy measures. On the other hand, we contrast and extend Aguirre and Ibikunle (2014) who found a negative effect of fiscal and financial incentives. We disentangle this view, showing that FIT and grants and subsidies can have positive effects; however, we do find a negative effect for taxes.

Institutional investors' decisions are supported through direct influence on the return side of their investment calculations. Higher income through grants and subsidies and lower capital costs through FITs support their openness towards RE investments (Lüthi and Wüstenhagen, 2012). Tax regulation does not necessarily have conducive effects as many institutional investors already have a tax optimised corporate structure. 
Table 3

Ordinary least square (OLS) regression results.

\begin{tabular}{|c|c|c|c|c|c|c|c|c|}
\hline \multirow[t]{3}{*}{ Independent variables (ANPM) $(t-1)$} & \multicolumn{8}{|l|}{ OLS } \\
\hline & \multicolumn{2}{|c|}{$\begin{array}{l}\text { Standard errors } \\
\text { Multiple RE } \\
\text { (V) }\end{array}$} & \multicolumn{2}{|c|}{$\begin{array}{l}\text { Standard errors } \\
\text { Wind } \\
(\mathrm{VI})\end{array}$} & \multicolumn{2}{|c|}{$\begin{array}{l}\text { Standard errors } \\
\text { Solar } \\
\text { (VII) }\end{array}$} & \multicolumn{2}{|c|}{$\begin{array}{l}\text { Standard errors } \\
\text { Biomass } \\
\text { (VIII) }\end{array}$} \\
\hline & Coeff. & S.E. & Coeff. & S.E. & Coeff. & S.E. & Coeff. & S.E. \\
\hline EI_FI_FI ${ }_{j k}$ & $0.69^{* * *}$ & 0.30 & $0.70 * * *$ & 0.26 & $1.18^{* * * * *}$ & 0.31 & 0.09 & 0.26 \\
\hline EI_FI_GS $_{\mathrm{jk}}$ & 0.33 & 0.26 & 0.13 & 0.25 & $0.61 * *$ & 0.25 & $0.61^{* * *}$ & 0.25 \\
\hline EI_FI_L ${ }_{j k}$ & -0.36 & 0.44 & 0.30 & 0.40 & $-0.91^{* * *}$ & 0.43 & -0.15 & 0.39 \\
\hline EI_FI_TR ${ }_{\mathrm{jk}}$ & 0.40 & 0.33 & 0.20 & 0.29 & -0.01 & 0.34 & 0.10 & 0.27 \\
\hline EI_FI_T ${ }_{j k}$ & $-0.90^{*}$ & 0.49 & -0.51 & 0.44 & $1.00^{*}$ & 0.58 & -0.20 & 0.39 \\
\hline EI_MI_GA $A_{\mathrm{jk}}$ & $1.48^{* *}$ & 0.67 & $1.59 * * *$ & 0.61 & -1.17 & 0.80 & 0.97 & 0.53 \\
\hline EI_MI_GC ${ }_{\mathrm{jk}}$ & -0.02 & 0.44 & -0.03 & 0.41 & $-2.27^{* * * * *}$ & 0.48 & 0.06 & 0.37 \\
\hline EI_DI_FSG ${ }_{j k}$ & -0.65 & 0.52 & -0.38 & 0.47 & $-1.43^{* * * *}$ & 0.47 & $1.51^{* * *}$ & 0.52 \\
\hline EI_DI_II ${ }_{j k}$ & 0.15 & 0.44 & 0.37 & 0.37 & 0.21 & 0.56 & $-1.20^{* * * * *}$ & 0.46 \\
\hline PS_IC $C_{j k}$ & -0.41 & 0.41 & 0.13 & 0.34 & -1.51 & 0.43 & $0.83^{* *}$ & 0.36 \\
\hline PS_SP ${ }_{\mathrm{jk}}$ & $0.70^{* *}$ & 0.35 & 0.16 & 0.36 & $2.35^{* * * *}$ & 0.34 & -0.44 & 0.30 \\
\hline RI_CS ${ }_{j k}$ & 0.45 & 0.33 & $0.63 * *$ & 0.32 & 0.54 & 0.36 & -0.41 & 0.33 \\
\hline RI_OS $_{\mathrm{jk}}$ & 0.28 & 0.39 & -0.09 & 0.35 & 0.16 & 0.41 & -0.01 & 0.34 \\
\hline RI_MR ${ }_{\mathrm{jk}}$ & 0.52 & 0.37 & 0.21 & 0.34 & $0.77^{*}$ & 0.47 & 0.28 & 0.31 \\
\hline \multicolumn{9}{|l|}{ Control variables } \\
\hline $\mathrm{C} \_\mathrm{TEC}_{\mathrm{jk}}$ & $0.64^{* * * *}$ & 0.19 & $0.77^{* * * *}$ & 0.20 & 0.95 & 0.72 & $-1.97^{* * * *}$ & 0.52 \\
\hline$c_{-} \mathrm{Cl}_{\mathrm{jk}}$ & -0.09 & 0.96 & 0.96 & 1.02 & $-6.01^{* *}$ & 2.58 & $4.37^{* * * *}$ & 1.60 \\
\hline C_LLIR ${ }_{\mathrm{jk}}$ & $-0.67 * * * *$ & 0.24 & $-0.74^{* * * * *}$ & 0.24 & -0.54 & 0.67 & $-0.57^{*}$ & 0.30 \\
\hline c_SP $P_{j k}$ & $1.84^{\text {*k*k* }}$ & 0.33 & $2.10^{* * * *}$ & 0.35 & -0.24 & 0.46 & $0.61^{*}$ & 0.37 \\
\hline C_GDP $P_{\mathrm{jk}}$ & -0.02 & 0.10 & -0.05 & 0.09 & -0.82 & 0.70 & $2.16^{\text {****** }}$ & 0.50 \\
\hline _cons & $-7.12^{* * * *}$ & 2.65 & $-8.33 * * *$ & 2.59 & 21.59 & 17.01 & $-53.24^{\text {****k }}$ & 11.51 \\
\hline Observations & \multicolumn{2}{|l|}{330} & \multicolumn{2}{|l|}{319} & \multicolumn{2}{|l|}{176} & \multicolumn{2}{|l|}{220} \\
\hline$R^{2}$ & \multicolumn{2}{|l|}{0.38} & \multicolumn{2}{|l|}{0.40} & \multicolumn{2}{|l|}{0.49} & \multicolumn{2}{|l|}{0.38} \\
\hline $\boldsymbol{F}$ & \multicolumn{2}{|l|}{$10.05^{\text {*k*k }}$} & \multicolumn{2}{|l|}{$10.93^{* * * *}$} & \multicolumn{2}{|l|}{$8.01 * * *$} & \multicolumn{2}{|l|}{$6.52^{* * * *}$} \\
\hline Mean VIF & \multicolumn{2}{|l|}{2.03} & \multicolumn{2}{|l|}{1.94} & \multicolumn{2}{|l|}{9.17} & \multicolumn{2}{|l|}{5.15} \\
\hline
\end{tabular}

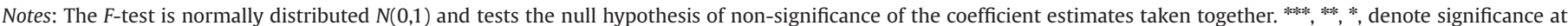
$1 \%, 5 \%$ and $10 \%$ significance levels, Estimations include both country and time dummies (Marques et al., 2010). regress command was used.

Table 4

Overview about the results.

\begin{tabular}{|c|c|c|c|c|c|c|c|c|}
\hline \multirow[t]{3}{*}{ Independent variables (ANPM) (t-1) } & \multicolumn{8}{|c|}{ Overview } \\
\hline & \multicolumn{2}{|c|}{ Multiple RE } & \multicolumn{2}{|l|}{ Wind } & \multicolumn{2}{|l|}{ Solar } & \multicolumn{2}{|l|}{ Biomass } \\
\hline & PCSE & OLS & PCSE & OLS & PCSE & OLS & PCSE & OLS \\
\hline EI_FI_FI $I_{j k}$ & $+(* * *)$ & $+(* *)$ & $+(* *)$ & $+(* * *)$ & $+\left({ }^{* * *}\right)$ & $+(* * * *)$ & $+(\mathrm{NS})$ & $+(\mathrm{NS})$ \\
\hline EI_FI_GS $S_{\mathrm{jk}}$ & $+(\mathrm{NS})$ & $+(\mathrm{NS})$ & $+(\mathrm{NS})$ & $+(\mathrm{NS})$ & $+(* * *)$ & $+(* *)$ & $+(* *)$ & $+\left({ }^{* * *}\right)$ \\
\hline EI_FI_L $\mathrm{j}_{\mathrm{jk}}$ & $-(\mathrm{NS})$ & $-(\mathrm{NS})$ & $+(\mathrm{NS})$ & $+(\mathrm{NS})$ & $-(* * *)$ & $-\left({ }^{* * *}\right)$ & $-(\mathrm{NS})$ & $-(\mathrm{NS})$ \\
\hline EI_FI_TR $\mathrm{jk}_{\mathrm{jk}}$ & $+(* *)$ & $+(\mathrm{NS})$ & $+(\mathrm{NS})$ & $+(\mathrm{NS})$ & $-(\mathrm{NS})$ & $-(\mathrm{NS})$ & $+(\mathrm{NS})$ & $+(\mathrm{NS})$ \\
\hline EI_FI_T ${ }_{j k}$ & $-\left({ }^{*}\right)$ & $-\left({ }^{*}\right)$ & $-(\mathrm{NS})$ & $-(\mathrm{NS})$ & $+(* *)$ & $+(*)$ & $-(\mathrm{NS})$ & $-(\mathrm{NS})$ \\
\hline EI_MI_GA $A_{j k}$ & $+\left({ }^{* *}\right)$ & $+(* *)$ & $+(* * *)$ & $+(* * *)$ & $-\left({ }^{* * *}\right)$ & $-(\mathrm{NS})$ & $+(*)$ & $+(\mathrm{NS})$ \\
\hline EI_MI_GC ${ }_{\mathrm{jk}}$ & $-(\mathrm{NS})$ & $-(\mathrm{NS})$ & $-(\mathrm{NS})$ & $-(\mathrm{NS})$ & $-\left({ }^{* * *}\right)$ & $-(* * *)$ & $+(\mathrm{NS})$ & $+(\mathrm{NS})$ \\
\hline EI_DI_FSG $\mathrm{jk}_{\mathrm{j}}$ & $-(*)$ & $-(\mathrm{NS})$ & $-(\mathrm{NS})$ & $-(\mathrm{NS})$ & $-\left({ }^{* * *}\right)$ & $-(* * * *)$ & $+(* * *)$ & $+\left({ }^{* * *}\right)$ \\
\hline EI_DI_II ${ }_{j k}$ & $+(\mathrm{NS})$ & $+(\mathrm{NS})$ & $+(\mathrm{NS})$ & $+(\mathrm{NS})$ & $+(\mathrm{NS})$ & $+(\mathrm{NS})$ & $-(* *)$ & $-(* * *)$ \\
\hline PS_IC $C_{\mathrm{jk}}$ & $-(\mathrm{NS})$ & $-(\mathrm{NS})$ & $+(\mathrm{NS})$ & $+(\mathrm{NS})$ & $-\left({ }^{* * * *}\right)$ & $-(\mathrm{NS})$ & $+(* *)$ & $+\left({ }^{* * *}\right)$ \\
\hline PS_SP ${ }_{j k}$ & $+\left(^{*}\right)$ & $+\left({ }^{* *}\right)$ & $+(\mathrm{NS})$ & $+(\mathrm{NS})$ & $+(* * *)$ & $+(* * * *)$ & $-\left({ }^{*}\right)$ & $-(\mathrm{NS})$ \\
\hline RI_CS $S_{j k}$ & $+\left(^{* * * *}\right)$ & $+(\mathrm{NS})$ & $+(* *)$ & $+(* *)$ & $+(* *)$ & $+(\mathrm{NS})$ & $-(\mathrm{NS})$ & $-(\mathrm{NS})$ \\
\hline RI_OS ${ }_{j k}$ & $+(\mathrm{NS})$ & $+(\mathrm{NS})$ & $-(\mathrm{NS})$ & $-(\mathrm{NS})$ & $+(\mathrm{NS})$ & $+(\mathrm{NS})$ & $-(\mathrm{NS})$ & $-(\mathrm{NS})$ \\
\hline RI_MR $\mathrm{jk}_{\mathrm{jk}}$ & $+(\mathrm{NS})$ & $+(\mathrm{NS})$ & $+(\mathrm{NS})$ & $+(\mathrm{NS})$ & $+(* *)$ & $+\left({ }^{*}\right)$ & $+(\mathrm{NS})$ & $+(\mathrm{NS})$ \\
\hline \multicolumn{9}{|l|}{ Control variables } \\
\hline$c_{-} \mathrm{TEC}_{\mathrm{jk}}$ & $+(\mathrm{NS})$ & $+(* * *)$ & $+(* * *)$ & $+(* * *)$ & $+(\mathrm{NS})$ & $+(\mathrm{NS})$ & $-(* * *)$ & $-\left({ }^{* * * *}\right)$ \\
\hline$c_{-} \mathrm{Cl}_{\mathrm{jk}}$ & $-(\mathrm{NS})$ & $-(\mathrm{NS})$ & $+(* *)$ & $+(\mathrm{NS})$ & $-\left({ }^{* * * *}\right)$ & $-\left({ }^{* * *}\right)$ & $+(* * * *)$ & $+(* * *)$ \\
\hline c_LLIR ${ }_{\mathrm{jk}}$ & $-\left(^{* * * * *}\right)$ & $-(* * *)$ & $-(* * *)$ & $-(* * *)$ & $-(\mathrm{NS})$ & $-(\mathrm{NS})$ & $-\left({ }^{* * *}\right)$ & $-(*)$ \\
\hline c_SP $P_{j k}$ & $+(* * * *)$ & $+(* * *)$ & $+\left(^{* * *}\right)$ & $+(* * *)$ & $-(\mathrm{NS})$ & $-(\mathrm{NS})$ & $+(\mathrm{NS})$ & $+\left({ }^{*}\right)$ \\
\hline c_GDP $\mathrm{jk}_{\mathrm{j}}$ & $-(\mathrm{NS})$ & $-(\mathrm{NS})$ & $-(\mathrm{NS})$ & $-(\mathrm{NS})$ & $-(\mathrm{NS})$ & $-(\mathrm{NS})$ & $+\left({ }^{* * * *}\right)$ & $+\left({ }^{* * * *}\right)$ \\
\hline _cons & $-(* *)$ & $-\left(^{(* * *)}\right)$ & $-(* *)$ & $-(* * *)$ & $+(\mathrm{NS})$ & $+(\mathrm{NS})$ & $-(* * * *)$ & $-(* * *)$ \\
\hline $\mathrm{R}^{2}$ & 0.38 & 0.38 & 0.40 & 0.40 & 0.49 & 0.49 & 0.38 & 0.38 \\
\hline
\end{tabular}

NS refers to 'not statistically significant'.

*** Significance at $1 \%$ significance levels.

** Significance at $5 \%$ significance levels.

* Significance at 10\% significance levels. 
Table A1

Country selection.

\begin{tabular}{|c|c|c|c|}
\hline Countries included in Multiple RE & Countries included in Solar & Countries included in Wind & Countries included in Biomass \\
\hline $\begin{array}{l}\text { Australia, Austria, Belgium, Canada, Chile, } \\
\text { Czech Republic, Denmark, Estonia, } \\
\text { Finland, France, Germany, Greece, } \\
\text { Hungary, Ireland, Italy, Japan, Korea, } \\
\text { Rep., Mexico, Netherlands, New Zeal- } \\
\text { and, Norway, Poland, Portugal, Slovak } \\
\text { Republic, Spain, Sweden, Switzerland, } \\
\text { Turkey, United Kingdom, United States }\end{array}$ & $\begin{array}{l}\text { Australia, Belgium, Canada, Czech Re- } \\
\text { public, France, Germany, Greece, Italy, } \\
\text { Japan, Korea, Rep., Netherlands, Portu- } \\
\text { gal, Slovak Republic, Spain, Turkey, } \\
\text { United Kingdom, United States }\end{array}$ & $\begin{array}{l}\text { Australia, Austria, Belgium, Canada, } \\
\text { Chile, Czech Republic, Denmark, Esto- } \\
\text { nia, Finland, France, Germany, Greece, } \\
\text { Hungary, Ireland, Italy, Japan, Korea, } \\
\text { Rep., Mexico, Netherlands, New Zeal- } \\
\text { and, Norway, Poland, Portugal, Spain, } \\
\text { Sweden, Switzerland, Turkey, United } \\
\text { Kingdom, United States }\end{array}$ & $\begin{array}{l}\text { Australia, Austria, Belgium, Canada, } \\
\text { Chile, Czech Republic, Finland, France, } \\
\text { Germany, Ireland, Italy, Japan, Mexico, } \\
\text { Netherlands, Norway, Poland, Spain, } \\
\text { Sweden, United Kingdom, United States }\end{array}$ \\
\hline
\end{tabular}

\subsection{Market-based incentives}

Our analysis also provides mixed evidence for market based incentives such as emission trading schemes and green certificate schemes on subsequent RE investments. GHG emission trading systems have been introduced in the US, Australia, UK, Italy and Norway since 1991. First, aggregated results as well as sectoral results from the wind and biomass sectors highlight the robust positive influence of tradable permit systems. This might be due to the fact that on the one hand wind energy can be installed in relevant capacities. On the other hand biomass plants generate a constant flow of certificate an exhibit base-load characteristics. We thereby confirm earlier literature on GHG systems (Helm, 2002; Quirion, 2010; Rogge et al., 2011; Rogge and Hoffmann, 2010; Smith and Swierzbinski, 2007).

Interestingly, the presence of GHG emissions allowances have a stronger impact on the capacity financed by institutional investors than FIT, as investors prefer market-based systems which are less dependent on policy changes which is the case in aggregated results and the wind and biomass sectors. Our results add empirical evidence to the debate revolving around FITs and tradable permits (Butler and Neuhoff, 2008; Cansino et al., 2010).

On the other hand, GHG emissions allowances show a negative impact on the capacity financed by institutional investors in the solar sector. Solar energy technologies, being less mature, costeffective and more diverse than wind, are more heavily dependent on regulation, although grid parity is almost reached. These developments are reflected in our results regarding the policy mix. Market based incentives (such as GHG emission trading systems) prove to be ineffective in this case. A possible explanation lies in the fact, that solar technologies require stronger signals towards investors due to their relative novelty compared to wind technologies. We thereby confirm Johnstone et al. (2010) who found that market based approaches favour technologies (such as wind) that are closer to competitiveness with fossil fuels whereas feed-in tariffs are conducive to innovation in less mature technologies (such as solar).

Second, green certificates that permit trading the obligatory RE capacity in a national scheme do not incentivise institutional investors to install more solar capacity which might be due to the lack in maturity and the low amount of certificates generated per capital invested compared to other sectors, such as wind. These measures depend on the total quantity in the market which might vary resulting in insufficient mobilisation of funds and high regulatory uncertainty. In addition, quota-based systems tend to be opaque as they involve over-the-counter transactions for certificates (Cárdenas-Rodríguez et al., 2013). Our results contrast Szabó and Jäger-Waldau (2008) as well as Jensen and Skytte (2002) who conceptualised a positive influence of these renewable certificate markets. In sum, institutional investors like the openness of market based policy measures, as long as they promise reliable support for their investments (Chassot et al., 2014). Possible risks through technological or natural uncertainties lead to hard to calculate returns which lower the appetite for investments into RE.

\subsection{Direct investments}

According to our results from the biomass sector positive contributions with high significance include funds to sub-national governments (direct investments of federal money with regional, local or municipal level entities as intermediaries or targets) as biomass markets tend to be regionally dispersed. We hereby confirm earlier works (based on wind sector analyses) which highlighted that this form of direct investment spurs RE deployment (Bird et al., 2005; De Jager et al., 2008; Menz and Vachon, 2006; Ragwitz et al., 2008). Our results from the solar sector revealed that this type of instrument is ineffective in promoting solar capacity addition. This might be due to the fact that institutional investors ignore subsidies on a local level.

Infrastructure investments to provide grid access seem ineffective for channelling investor's money into biomass technologies. This stands in contrast to previous literature which highlights the grid expansion as conducive to RE deployment and investment (De Jager et al., 2011; Henriot, 2013; Steinbach, 2013). Reasons for deviating results in the biomass energy sector (compared to solar and wind) lie in the different structure which can be characterised by a strong regional focus and usually the small scale of power plants (Upreti, 2004). This might attract a different set of investors that focus less on overall market conditions.

\subsection{Policy support}

When examining the influence of policy support measures on subsequent investments into RE capacity, our results show interesting characteristics. First, institutional creation, such as the implementation of an energy agency, accelerates the capacity additions in the biomass sector effectively. Results from the solar sector show the contrary. A possible explanation lies in the fact that the sudden cut in the Spanish feed-in tariff system is coded as an institutional creation/change.

Secondly, aggregated and solar sector results show that a clear long-term energy strategy (strategic planning) is conducive to investments as investors favour a long-term framework with a clear vision. Essentially, all countries in our study had policy measures containing a strategic component, however only a few incorporated it in many policy initiatives.

With this analysis, we add empirical support for the strong role which a long-term policy commitment (strategic planning) plays in an effective policy mix. De Jager et al. (2011) state that commitment, stability, reliability and predictability are all elements that increase confidence of market actors, reduce regulatory risks, and hence significantly reduce cost of capital. Additional evidence points towards a preference for policy consistency even when changes occur (White et al., 2013). Thus, our results confirm conceptual and empirical works by several scholars, which hold clear strategic long-term economic instruments to be conducive to 
Table A2

Data-definition, sources and descriptive statistics.

\begin{tabular}{|c|c|c|c|c|c|c|c|c|}
\hline Category & Variable & Definition & Source & Obs. & Mean & Std. dev. & Min & $\operatorname{Max}$ \\
\hline \multirow[t]{4}{*}{ Dependent variables } & BNEF_Capacity_ALL $\mathrm{jk}_{\mathrm{j}}$ & $\begin{array}{l}\text { Logarithm of the installed capacity additions of multiple renewable energy sources (ag- } \\
\text { gregated from BNEF_Capacity_Biomass } \mathrm{j}_{\mathrm{jk}} \text {, BNEF_Capacity_Solar } \mathrm{j}_{\mathrm{jk}} \text {, BNEF_Capacity_Wind } \mathrm{j}_{\mathrm{jk}} \text { ) }\end{array}$ & $\begin{array}{l}\text { Bloomberg New Energy Fi- } \\
\text { nance (BNEF) }\end{array}$ & 360 & 3.61 & 2.81 & 0 & 9.43 \\
\hline & BNEF_Capacity_Biomass $s_{\mathrm{jk}}$ & Logarithm of the installed capacity additions of biomass capacity & $\begin{array}{l}\text { Bloomberg New Energy Fi- } \\
\text { nance (BNEF) }\end{array}$ & 240 & 2.25 & 2.09 & 0 & 6.80 \\
\hline & BNEF_Capacity_Solar $r_{\mathrm{jk}}$ & Logarithm of the installed capacity additions of solar capacity & $\begin{array}{l}\text { Bloomberg New Energy Fi- } \\
\text { nance (BNEF) }\end{array}$ & 192 & 1.76 & 2.27 & 0 & 8.56 \\
\hline & BNEF_Capacity_Wind $\mathrm{jk}_{\mathrm{j}}$ & Logarithm of the installed capacity additions of wind capacity & $\begin{array}{l}\text { Bloomberg New Energy Fi- } \\
\text { nance (BNEF) }\end{array}$ & 348 & 3.34 & 2.81 & 0 & 9.17 \\
\hline \multirow[t]{5}{*}{$\begin{array}{l}\text { Economic Instruments-Fiscal/financial } \\
\text { incentives (EI_FI) }\end{array}$} & EI_FI_FI ${ }_{j k}$ & Logarithm of ANPM (feed-in tariffs/premiums) & $\begin{array}{l}\text { IEA policies and measures } \\
\text { database }\end{array}$ & 360 & 0.48 & 0.52 & 0 & 1.95 \\
\hline & EI_FI_GS $S_{\mathrm{jk}}$ & Logarithm of ANPM (grants and subsidies) & $\begin{array}{l}\text { IEA policies and measures } \\
\text { database }\end{array}$ & 360 & 0.88 & 0.64 & 0 & 2.30 \\
\hline & EI_FI_L $\mathrm{j}_{\mathrm{jk}}$ & Logarithm of ANPM (loans) & $\begin{array}{l}\text { IEA policies and measures } \\
\text { database }\end{array}$ & 360 & 0.25 & 0.38 & 0 & 1.61 \\
\hline & EI_FI_TR $\mathrm{jk}_{\mathrm{jk}}$ & Logarithm of ANPM (tax relief) & $\begin{array}{l}\text { IEA policies and measures } \\
\text { database }\end{array}$ & 360 & 0.40 & 0.52 & 0 & 1.79 \\
\hline & EI_FI_T $\mathrm{T}_{\mathrm{jk}}$ & Logarithm of ANPM (taxes) & $\begin{array}{l}\text { IEA policies and measures } \\
\text { database }\end{array}$ & 360 & 0.27 & 0.37 & 0 & 1.10 \\
\hline \multirow[t]{2}{*}{$\begin{array}{l}\text { Economic Instruments -Market-based } \\
\text { instruments (EI_MI) }\end{array}$} & EI_MI_GA ${ }_{\mathrm{jk}}$ & Logarithm of ANPM (GHG emissions allowances) & $\begin{array}{l}\text { IEA policies and measures } \\
\text { database }\end{array}$ & 360 & 0.10 & 0.29 & 0 & 1.39 \\
\hline & EI_MI_GC $C_{\mathrm{jk}}$ & Logarithm of ANPM (green certificates) & $\begin{array}{l}\text { IEA policies and measures } \\
\text { database }\end{array}$ & 360 & 0.19 & 0.37 & 0 & 1.61 \\
\hline \multirow[t]{2}{*}{$\begin{array}{l}\text { Economic Instruments-Direct invest- } \\
\text { ment (EI_DI) }\end{array}$} & EI_DI_FSG ${ }_{\mathrm{jk}}$ & Logarithm of ANPM (funds to sub-national governments) & $\begin{array}{l}\text { IEA policies and measures } \\
\text { database }\end{array}$ & 360 & 0.16 & 0.32 & 0 & 1.39 \\
\hline & EI_DI_II $j_{\mathrm{jk}}$ & Logarithm of ANPM (infrastructure investments) & $\begin{array}{l}\text { IEA policies and measures } \\
\text { database }\end{array}$ & 360 & 0.17 & 0.36 & 0 & 1.60 \\
\hline \multirow[t]{2}{*}{ Policy Support (PS) } & PS_IC $C_{\mathrm{jk}}$ & Logarithm of ANPM (institutional creation) & $\begin{array}{l}\text { IEA policies and measures } \\
\text { database }\end{array}$ & 360 & 0.47 & 0.49 & 0 & 1.95 \\
\hline & PS_SP $P_{j k}$ & Logarithm of ANPM (strategic planning) & $\begin{array}{l}\text { IEA policies and measures } \\
\text { database }\end{array}$ & 360 & 0.87 & 0.56 & 0 & 2.08 \\
\hline \multirow[t]{3}{*}{ Regulatory Instruments (RI) } & $\mathrm{RI}_{-} \mathrm{CS}_{\mathrm{jk}}$ & Logarithm of ANPM (codes and standards) & $\begin{array}{l}\text { IEA policies and measures } \\
\text { database }\end{array}$ & 360 & 0.51 & 0.52 & 0 & 2.40 \\
\hline & RI_OS $_{\mathrm{jk}}$ & Logarithm of ANPM (obligation schemes) & $\begin{array}{l}\text { IEA policies and measures } \\
\text { database }\end{array}$ & 360 & 0.64 & 0.51 & 0 & 2.08 \\
\hline & RI_MR $R_{j k}$ & Logarithm of ANPM (other mandatory requirements) & $\begin{array}{l}\text { IEA policies and measures } \\
\text { database }\end{array}$ & 360 & 0.46 & 0.56 & 0 & 2.30 \\
\hline \multirow[t]{5}{*}{ Control variables } & $c_{-} \mathrm{TEC}_{\mathrm{jk}}$ & Logarithm of total energy consumption & World bank & 360 & 3.50 & 1.18 & 1.23 & 6.96 \\
\hline & $\mathrm{c}_{-} \mathrm{Cl}_{\mathrm{jk}}$ & $\begin{array}{l}\text { Logarithm of } \mathrm{CO}_{2} \text { intensity-metric tons of carbon dioxide per thousand year } 2005 \text { U.S. } \\
\text { dollars GDP }\end{array}$ & EIA & 360 & 0.34 & 0.17 & 0.10 & 0.99 \\
\hline & $\mathrm{C} \_L I R_{\mathrm{jk}}$ & Logarithm of long-term interest rates & OECD & 360 & 1.52 & 0.60 & 0 & 2.82 \\
\hline & ${\mathrm{C} \_S P_{\mathrm{jk}}}_{2}$ & Logarithm of share prices (index) & OECD & 360 & 4.49 & 0.49 & 2.90 & 5.70 \\
\hline & $\mathrm{C}_{-} \mathrm{GDP}_{\mathrm{jk}}$ & Logarithm of real gross domestic product (in billions U.S. dollars, 2013) & World bank & 360 & 26.72 & 2.00 & 0 & 30.34 \\
\hline
\end{tabular}




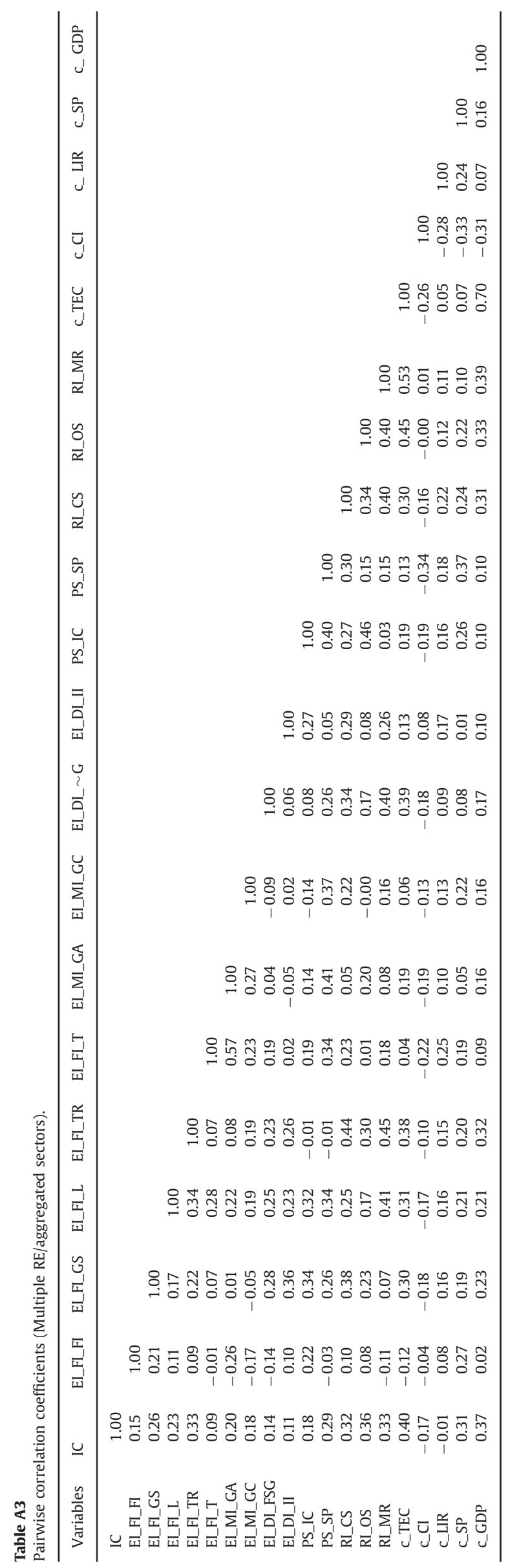

RE investments (Lüthi and Wüstenhagen, 2012; White et al., 2013; Wüstenhagen and Menichetti, 2012). Finally, we confirm work by Marques and Fuinhas (2012a) who highlight the policy processes and strategy frameworks as positive for RE deployment. Possible risks through instability in regulation directly affect investors' return calculations and determine investment decisions immediately (Wüstenhagen and Menichetti, 2012). Therefore, a longterm vision for the regulatory environment through strategic planning and most likely through institutional creation will support the investment environment for institutional investors.

\subsection{Regulatory instruments}

Regulatory mechanisms and institutionalisation of markets in the form of codes and standards (especially RPS) also attract institutional investors. According to our results this is the case for the aggregated sectors as well as in the wind sector, perhaps because the wind sector shows elements of a developed market based on mature technologies. The cost-effectiveness of this technology is proven, so it can compete with fossil fuel-based electricity generation in certain environments.

We also provide new insights in the discussion about RPS schemes. Looking at US states, Carley (2009) found a positive effect, whereas Delmas and Montes-Sancho (2011) did not find a significant positive contribution of RPS to RE investments. Thus, we confirm Carley (2009), Bird et al. (2005), and Menz and Vachon (2006) for a sample of countries beyond the USA. On the other hand, we contrast Delmas and Montes-Sancho (2011). Reliable support through codes and standards or obligation schemes supports investments into RE through institutional investors. These policy measures are mostly long term and not easily retractable, so it gives them certainty in their investment calculations.

\subsection{Robustness checks}

We performed a number of robustness checks to verify the stability of our results. First of all we estimated pooled OLS regressions (which have the strongest assumptions with regard to heteroskedasticy and auto-correlation as well as distribution of errors) and calculated the variance inflation factors (VIF). The analysis revealed that only in the model for the solar sector, multicollinearity might be an issue (mean of VIF 9.17). However, this high value stems from the VIF of our control variables and therefore has no influence on the coefficients of our independent variables of interest (i.e. the policy measures). Second, we estimated random effects estimators (REE) for our models (see Table A4). All our models (PCSE, OLS and REE) display consistent results. When using the OLS model, grants and subsidies as well as codes and standards become insignificant. Third, we ran our models, including only the significant variables from our previous analysis. These analysis displayed consistent results throughout all models. Finally, to account for the excessive number of zeros in our sample, we crosschecked the disaggregated results (i.e. individual policy instruments) with aggregated results (categories of policy instruments) for the entire analysis. The models displayed consistent results.

\section{Conclusions and policy implications}

This work contributes to two different streams of the academic literature: Exploring the effectiveness of RE policies as well as observing the role of policies in the decision making process for RE capacity investments through institutional investors. Our research revealed mixed evidence from the wind, solar and biomass sector. We call for technology specific policies, taking into account the 
Table A4

Random effects estimator (REE) regression results.

\begin{tabular}{|c|c|c|c|c|c|c|c|c|}
\hline \multirow[t]{3}{*}{ Independent variables (ANPM) $(t-1)$} & \multicolumn{8}{|c|}{ Random effects } \\
\hline & \multicolumn{2}{|c|}{$\begin{array}{l}\text { CSE } \\
\text { Multiple RE } \\
\text { (IX) }\end{array}$} & \multicolumn{2}{|l|}{$\begin{array}{l}\text { CSE } \\
\text { Wind } \\
(X)\end{array}$} & \multicolumn{2}{|l|}{$\begin{array}{l}\text { CSE } \\
\text { Solar } \\
(\mathrm{XI})\end{array}$} & \multicolumn{2}{|l|}{$\begin{array}{l}\text { CSE } \\
\text { Biomass } \\
(\mathrm{XII})\end{array}$} \\
\hline & Coeff. & S.E. & Coeff. & S.E. & Coeff. & S.E. & Coeff. & S.E. \\
\hline EI_FI_FI $I_{j k}$ & $0.65^{*}$ & 0.38 & $0.61^{*}$ & 0.36 & $1.18^{* * * *}$ & 0.31 & 0.09 & 0.26 \\
\hline EI_FI_GS ${ }_{\mathrm{jk}}$ & $0.98^{* * * *}$ & 0.36 & $0.83^{* *}$ & 0.36 & $0.61^{* *}$ & 0.25 & $0.61^{* * * *}$ & 0.25 \\
\hline EI_FI_L $L_{j k}$ & -0.38 & 0.55 & 0.66 & 0.53 & $-0.91^{* *}$ & 0.43 & -0.15 & 0.39 \\
\hline EI_FI_TR ${ }_{j k}$ & 0.36 & 0.43 & -0.02 & 0.42 & -0.01 & 0.34 & 0.10 & 0.27 \\
\hline EI_FI_T $\mathrm{T}_{\mathrm{jk}}$ & $-1.43^{* *}$ & 0.59 & -0.50 & 0.58 & $1.00^{*}$ & 0.58 & -0.20 & 0.39 \\
\hline EI_MI_GA $A_{\mathrm{jk}}$ & $2.06 * * * *$ & 0.80 & $1.46^{*}$ & 0.83 & -1.17 & 0.80 & $0.97 * *$ & 0.53 \\
\hline EI_MI_GC & 0.15 & 0.56 & 0.24 & 0.52 & $-2.27^{* * * *}$ & 0.48 & 0.06 & 0.37 \\
\hline EI_DI_FSG ${ }_{\mathrm{jk}}$ & -1.12 & 0.71 & -1.11 & 0.70 & $-1.43^{* * * *}$ & 0.47 & $1.51^{* * * *}$ & 0.52 \\
\hline EI_DI_II ${ }_{j k}$ & 0.12 & 0.52 & 0.52 & 0.46 & 0.21 & 0.56 & $-1.20^{* * * * *}$ & 0.46 \\
\hline PS_IC $C_{\mathrm{jk}}$ & -0.55 & 0.48 & 0.02 & 0.45 & $-1.51^{* * * *}$ & 0.43 & $0.83^{* *}$ & 0.36 \\
\hline PS_SP $\mathrm{jk}_{\mathrm{jk}}$ & $1.20^{* * * *}$ & 0.42 & 0.66 & 0.43 & $2.35^{* * * *}$ & 0.34 & -0.44 & 0.30 \\
\hline RI_CS ${ }_{\mathrm{jk}}$ & $0.82^{*}$ & 0.48 & $1.03^{* *}$ & 0.47 & 0.54 & 0.36 & -0.41 & 0.33 \\
\hline RI_OS ${ }_{\mathrm{jk}}$ & 0.35 & 0.48 & 0.26 & 0.47 & 0.16 & 0.41 & -0.01 & 0.34 \\
\hline RI_MR $\mathrm{jk}_{\mathrm{jk}}$ & 0.73 & 0.46 & 0.04 & 0.43 & 0.77 & 0.47 & 0.28 & 0.31 \\
\hline \multicolumn{9}{|l|}{ Control variables } \\
\hline$c_{-} \mathrm{TEC}_{\mathrm{jk}}$ & $0.62 * *$ & 0.28 & 0.83 & 0.30 & 0.95 & 0.72 & $-1.97 * * *$ & 0.52 \\
\hline c_Cl $\mathrm{jk}_{\mathrm{jk}}$ & -0.66 & 1.60 & -0.38 & 1.80 & $-6.01^{* * *}$ & 2.58 & $4.37^{* * * *}$ & 1.60 \\
\hline${\mathrm{C} \_L I R_{\mathrm{jk}}}$ & $-0.71^{* *}$ & 0.31 & $-0.75^{* *}$ & 0.31 & -0.54 & 0.67 & $-0.57^{*}$ & 0.30 \\
\hline c_SP $P_{j k}$ & $1.84^{* * * *}$ & 0.36 & $1.92^{* * * *}$ & 0.37 & -0.24 & 0.46 & $0.61^{*}$ & 0.37 \\
\hline c_GDP ${ }_{\mathrm{jk}}$ & -0.04 & 0.08 & -0.05 & 0.08 & -0.82 & 0.70 & $2.16^{* * * * k}$ & 0.50 \\
\hline \multirow[t]{2}{*}{ _cons } & $-7.54^{* * * *}$ & 2.79 & $-8.64^{* * * *}$ & 2.80 & 21.59 & 17.02 & - & 11.51 \\
\hline & & & & & & & $53.24^{* * * * *}$ & \\
\hline Observations & \multicolumn{2}{|l|}{330} & \multicolumn{2}{|l|}{319} & \multicolumn{2}{|l|}{176} & \multicolumn{2}{|l|}{220} \\
\hline$R^{2}$ & \multicolumn{2}{|l|}{0.36} & \multicolumn{2}{|l|}{0.36} & \multicolumn{2}{|l|}{0.49} & \multicolumn{2}{|l|}{0.38} \\
\hline Wald & \multicolumn{2}{|l|}{$205.74^{* * * * *}$} & \multicolumn{2}{|l|}{$198.02^{* * * *}$} & \multicolumn{2}{|l|}{$152.19^{* * * *}$} & \multicolumn{2}{|l|}{$123.86^{\text {***k* }}$} \\
\hline
\end{tabular}

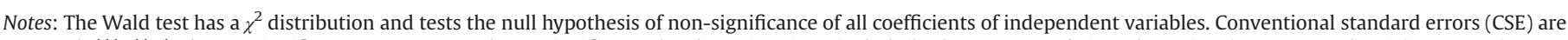

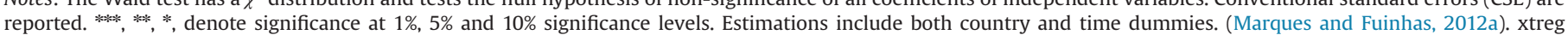
command was used.

actual market conditions and the position in the technology life cycle to design a supportive policy mix. Our results strongly suggest the establishment of a reliable framework with a clear vision and long-term policy objectives regarding the RE capacities to be installed in the future as well as complementary transitions in the energy sector. Ex-post changes to the remuneration of existing projects should be avoided. However, as technological progress continues, the measures taken need to be adjusted, taking the market and technological conditions (i.e. life cycle) into account.

Within this framework, monetary and fiscal and economic incentives are the most relevant policy measures for investors. These directly impact the risk/return profile of RE projects and, thus, their attractiveness. Investors are positive about long-term reliable support mechanisms that cannot be revoked and provide a highly predictable revenue stream. FIT provide a more reliable and longterm signal than grants which depend on public budgets. However these funds influence the direct and early project cash flows, which is also seen favourable.

According to our results, market based incentives (such as GHG emission trading systems) can also have strong influence on investments by institutional investors. These measures support the need of investors for a highly reliable environment, best accompanied by a diminished risk exposure. However, for an emission trading system to become an effective anchor for institutional investors, the technology deployed should have reached maturity.

Supportive regulatory measures such as codes and standards (especially RPS) accelerate the diffusion process of RE technologies by further reducing technological and regulatory risk associated with investments in RE projects. Thus we recommend the streamlining and strengthening of legislation and a transparent setting of renewable energy targets.

Our results also provide implications for institutional RE investors who are looking for stable returns unrelated to volatile capital markets. They recognize a regulatory environment which supports their investments or lowers their risks. We suggest them to allocate their funds in countries which have shown to be longterm supporters of the RE markets and have not changed policies abruptly. Higher certainty in the reliability of RE technologies and increasing cost competitiveness make the market increasingly independent from direct support mechanisms. To further accelerate diffusion the policy focus can move towards a reliable environment for RE.

There are a number of limitations regarding study design and modelling. First, the use of dummy variables for the policy measures does not allow for statements concerning policy implementation, policy design or policy uncertainty (Bergek et al., 2013; Jenner et al., 2013; Lüthi and Wüstenhagen, 2012; Müller et al., 2011). Second, our analysis does not cover the most recent developments in RE deployment and investments (2012 onwards) due to data availability.

Amending our fine grained policy analysis, future studies could look at the influence of these and other policies on general capacity additions among different types of private and institutional investors such as banks, insurances, university endowments, pension funds and family offices as well as including non-institutional investments such as households and utilities. Furthermore, interaction effects between the different policy instruments are worthwhile investigating in a longitudinal research design to discover complementarities and synergies. Geographically our research could be extended to the BRIC countries and less 
developed countries (LDC) which might alter the results due to an different institutional setting (Friebe et al., 2014, 2013). Finally, it would be interesting to close the link between early stage and later stage financing along the finance value chain for RE technologies, thus analysing the support environment for venture capital and private equity investments in the early and later stages of RE companies which might interact with RE project investments.

\section{Acknowledgements}

The authors are grateful for the time and support of Martin Kenney, Donald Patton (University of California, Davis), Alex Coad, and Paul Nightingale (SPRU-University of Sussex). We thank six anonymous reviewers for useful comments and suggestions. In addition the discussion at the ZEW Energy Conference 2014 helped us in further refining our arguments. We would like to thank the German Federal Ministry of Education and Research (BMBF), for their financial support as part of the research project "Climate Change, Financial Markets and Innovation (CFI)".

\section{Appendix A}

\section{A.1. Case selection}

The selection of countries for the aggregated and individual sector sample can be found here (Table A1).

\section{A.2. Summary statistics}

See Tables A2 and A3.

\section{A.3. Robustness checks}

See Table A4.

\section{References}

Aguirre, M., Ibikunle, G., 2014 Determinants of renewable energy growth: A global sample analysis. Energy Policy 69, 374-384. http://dx.doi.org/10.1016/j. enpol.2014.02.036.

Angrist, J.D., Pischke, J.-S., 2008. Mostly Harmless Econometrics: An Empiricist's Companion. Princeton University Press.

Arabatzis, G., Myronidis, D., 2011. Contribution of SHP Stations to the development of an area and their social acceptance. Renew. Sustain. Energy Rev. 15, 3909-3917. http://dx.doi.org/10.1016/j.rser.2011.07.026.

Barradale, M.J., 2010. Impact of public policy uncertainty on renewable energy investment: wind power and the production tax credit. Energy Policy 38, 7698-7709. http://dx.doi.org/10.1016/j.enpol.2010.08.021.

Bergek, A., Mignon, I., Sundberg, G., 2013. Who invests in renewable electricity production? Empirical evidence and suggestions for further research. Energy Policy 56, 568-581. http://dx.doi.org/10.1016/j.enpol.2013.01.038.

Bird, L.A., Bolinger, M., Gagliano, T., Wiser, R., Brown, M., Parsons, B., 2005. Policies and market factors driving wind power development in the United States. Energy Policy 33, 1397-1407. http://dx.doi.org/10.1016/j.enpol.2003.12.018.

BNEF, 2013. Bloomberg New Energy Finance (BNEF). Bloomberg.

Bolkesjø, T.F., Eltvig, P.T., Nygaard, E., 2014. An econometric analysis of support scheme effects on renewable energy investments in Europe. Energy Procedia, Renewable Energy Research Conference, RERC 2014 58, 2-8. doi: 10.1016/j. egypro.2014.10.401.

Butler, L., Neuhoff, K., 2008. Comparison of feed-in tariff, quota and auction mechanisms to support wind power development. Renew. Energy 33, 1854-1867.

Cameron, A.C., Trivedi, P.K., 2009. Microeconometrics Using Stata. Stata Press College Station, TX

Cansino, J.M., Pablo-Romero, M. del P., Román, R., Yñiguez, R., 2010. Tax incentives to promote green electricity: an overview of EU-27 countries. Energy Policy 38, 6000-6008.

Cárdenas-Rodríguez, M., Johnstone, N., Haščič, I., Silva, J., Ferey, A., 2013. Inducing private finance for renewable energy projects: Evidence from micro-data. OECD Environment Working Papers.

Carley, S., 2009. State renewable energy electricity policies: an empirical evaluation of effectiveness. Energy Policy 37, 3071-3081. http://dx.doi.org/10.1016/j. enpol.2009.03.062.

Chassot, S., Hampl, N., Wüstenhagen, R., 2014. When energy policy meets freemarket capitalists: the moderating influence of worldviews on risk perception and renewable energy investment decisions. Energy Res. Soc. Sci. 3, 143-151. http://dx.doi.org/10.1016/j.erss.2014.07.013.

Couture, T., Gagnon, Y., 2010. An analysis of feed-in tariff remuneration models: implications for renewable energy investment. Energy Policy 38, 955-965. http://dx.doi.org/10.1016/j.enpol.2009.10.047.

De Jager, D., Klessmann, C., Stricker, E., Winkel, T., de Visser, E., Koper, M., Ragwitz, M., Held, A., Resch, G., Busch, S., Panzer, C., Gazzo, A., Roulleau, T., Gousseland, P., Henriet, M., Bouillé, A., 2011. Financing Renewable Energy in the European Energy Market (No. PECPNL084659). Ecofys, Fraunhofer ISI, TU Vienna EEG, Ernst \& Young.

De Jager, D., Rathmann, M., Klessmann, C., Coenraads, R., Colamonico, C., Buttazzoni, M., 2008. Policy instrument design to reduce financing costs in renewable energy technology projects. Ecofys, by Order of the IEA Implementing Agreement on Renewable Energy Technology Deployment (RETD). Utrecht, the Netherlands.

Delmas, M.A., Montes-Sancho, M.J., 2011. U.S. state policies for renewable energy: Context and effectiveness. Energy Policy 39, 2273-2288. http://dx.doi.org/ 10.1016/j.enpol.2011.01.034.

Del Río, P., Bleda, M., 2012. Comparing the innovation effects of support schemes for renewable electricity technologies: a function of innovation approach. Energy Policy 50, 272-282. http://dx.doi.org/10.1016/j.enpol.2012.07.014.

Dinica, V., 2006. Support systems for the diffusion of renewable energy technologies-an investor perspective. Energy Policy 34, 461-480. http://dx.doi.org/ 10.1016/j.enpol.2004.06.014.

Eichhammer, W., Ragwitz, M., Schlomann, B., 2013. Introduction to the special issue: financing instruments to promote energy efficiency and renewables in times of tight public budgets. Energy \& Environment 24, 1-26. http://dx.doi. org/10.1260/0958-305X.24.1-2.1.

Foxon, T.J., Pearson, P.J.G., 2007. Towards improved policy processes for promoting innovation in renewable electricity technologies in the UK. Energy Policy 35, 1539-1550. http://dx.doi.org/10.1016/j.enpol.2006.04.009.

Frankfurt School-UNEP Centre, BNEF, 2014. Global Trends in Renewable Energy Investment 2014. Frankfurt am Main.

Friebe, C.A., Flotow, P. von, Täube, F.A., 2013. Exploring the link between products and services in low-income markets-evidence from solar home systems. Energy Policy 52, 760-769. http://dx.doi.org/10.1016/j.enpol.2012.10.038.

Friebe, C.A., von Flotow, P., Täube, F.A., 2014. Exploring technology diffusion in emerging markets-the role of public policy for wind energy. Energy Policy 70 217-226. http://dx.doi.org/10.1016/j.enpol.2014.03.016.

Hair, J., 2010. Multivariate Data Analysis: A Global Perspective, 7th ed Pearson Education, Upper Saddle River, NJ, London.

Haley, U.C.V., Schuler, D.A., 2011. Government policy and firm strategy in the solar photovoltaic industry. Calif. Manag. Rev. 54, 17-38. http://dx.doi.org/10.1525/ cmr.2011.54.1.17.

Harmelink, M., Voogt, M., Cremer, C., 2006. Analysing the effectiveness of renewable energy supporting policies in the European Union. Energy Policy, Renewable Energy Policies in the European Union 34, 343-351. http://dx.doi.org/ 10.1016/j.enpol.2004.08.031.

Helm, D., 2002. Energy policy: security of supply, sustainability and competition. Energy Policy 30, 173-184.

Henriot, A., 2013. Financing investment in the European electricity transmission network: consequences on long-term sustainability of the TSOs financial structure. Energy Policy 62, 821-829. http://dx.doi.org/10.1016/j. enpol.2013.07.011.

Hoyos, R.E.D., Sarafidis, V., 2006. Testing for cross-sectional dependence in paneldata models. Stata J. 6, 482-496.

IEA, 2013. Tracking Clean Energy Progress 2013. IEA, Paris.

IEA, 2014. IEA FAQ Renewable Energy [WWW Document]. URL 〈http://www.iea.org/ aboutus/faqs/renewableenergy/ $\rangle$.

IPCC, 2014. Climate Change 2014: Mitigation of Climate Change-IPCC Working Group III Contribution to AR5. Int, Berlin.

Jacobsson, S., Bergek, A., Finon, D., Lauber, V., Mitchell, C., Toke, D., Verbruggen, A. 2009. EU renewable energy support policy: faith or facts? Energy Policy 37, 2143-2146, http://dx.doi.org/10.1016/j.enpol.2009.02.043.

Jefferson, M., 2008. Accelerating the transition to sustainable energy systems. Energy Policy 36, 4116-4125. http://dx.doi.org/10.1016/j.enpol.2008.06.020.

Jenner, S., Groba, F., Indvik, J., 2013. Assessing the strength and effectiveness of renewable electricity feed-in tariffs in European Union countries. Energy Policy 52, 385-401. http://dx.doi.org/10.1016/j.enpol.2012.09.046.

Jensen, S.G., Skytte, K., 2002. Interactions between the power and green certificate markets. Energy Policy 30, 425-435. http://dx.doi.org/10.1016/S0301-4215(01) 00111-2.

Johnstone, N., Haščič, I., Popp, D., 2010. Renewable energy policies and technological innovation: evidence based on patent counts. Environ. Resource Econ. 45 133-155. http://dx.doi.org/10.1007/s10640-009-9309-1.

Kenney, M., Hargadon, A., 2012. Misguided policy? Calif. Manag. Rev. 54, 118-139. http://dx.doi.org/10.1525/cmr.2012.54.2.118

Lesser, J., Su, X., 2008. Design of an economically efficient feed-in tariff structure for renewable energy development. Energy Policy 36, 981-990.

Lüthi, S., Prässler, T., 2011. Analyzing policy support instruments and regulatory risk factors for wind energy deployment-a developers' perspective. Energy Policy 39, 4876-4892. http://dx.doi.org/10.1016/j.enpol.2011.06.029. 
Lüthi, S., Wüstenhagen, R., 2012. The price of policy risk-empirical insights from choice experiments with European photovoltaic project developers. Energy Econ. 34, 1001-1011. http://dx.doi.org/10.1016/j.eneco.2011.08.007.

Marques, A.C., Fuinhas, J.A., 2011. Do energy efficiency measures promote the use of renewable sources? Environ. Sci. Policy 14, 471-481. http://dx.doi.org/10.1016/j. envsci.2011.02.001.

Marques, A.C., Fuinhas, J.A., 2012a. Are public policies towards renewables successful? Evidence from European countries. Renew. Energy 44, 109-118. http: //dx.doi.org/10.1016/j.renene.2012.01.007.

Marques, A.C., Fuinhas, J.A., 2012b. Is renewable energy effective in promoting growth? Energy Policy 46, 434-442. http://dx.doi.org/10.1016/j. enpol.2012.04.006.

Marques, A.C., Fuinhas, J.A., Pires Manso, J.R., 2010. Motivations driving renewable energy in European countries: a panel data approach. Energy Policy 38 6877-6885. http://dx.doi.org/10.1016/j.enpol.2010.07.003.

Masini, A., Menichetti, E., 2012. The impact of behavioural factors in the renewable energy investment decision making process: conceptual framework and empirical findings. Energy Policy 40, 28-38. http://dx.doi.org/10.1016/j. enpol.2010.06.062.

Mathews, J.A., Kidney, S., Mallon, K., Hughes, M., 2010. Mobilizing private finance to drive an energy industrial revolution. Energy Policy 38, 3263-3265.

Menanteau, P., Finon, D., Lamy, M.-L., 2003. Prices versus quantities: choosing policies for promoting the development of renewable energy. Energy Policy 31, 799-812.

Menz, F.C., Vachon, S., 2006. The effectiveness of different policy regimes for promoting wind power: experiences from the states. Energy Policy 34, 1786-1796. http://dx.doi.org/10.1016/j.enpol.2004.12.018.

Mitchell, C., Bauknecht, D., Connor, P.M., 2006. Effectiveness through risk reduction: a comparison of the renewable obligation in England and Wales and the feed-in system in Germany. Energy Policy, Renewable Energy Policies in the European Union 34, 297-305. http://dx.doi.org/10.1016/j.enpol.2004.08.004.

Mowery, D.C., Nelson, R.R., Martin, B.R., 2010. Technology policy and global warming: why new policy models are needed (or why putting new wine in old bottles won't work). Res. Policy 39, 1011-1023.

Müller, S., Brown, A., Ölz, S., 2011. Renewable Energy: Policy Considerations for Deploying Renewables. International Energy Agency.

NREL, 2013. 2012 Renewable Energy Data Book. National Renewable Energy Laboratory.

OECD, 2013. OECD Factbook: Economic, Environmental and Social Statistics. OECD.

Olmos, L., Ruester, S., Liong, S.-J., 2012. On the selection of financing instruments to push the development of new technologies: application to clean energy technologies. Energy Policy 43, 252-266. http://dx.doi.org/10.1016/j. enpol.2012.01.001.

Popp, D., Hascic, I., Medhi, N., 2011. Technology and the diffusion of renewable energy. Energy Econ. 33, 648-662. http://dx.doi.org/10.1016/j. eneco.2010.08.007.
Quirion, P., 2010. Complying with the Kyoto Protocol under uncertainty: taxes or tradable permits? Energy Policy 38, 5166-5173.

Ragwitz, M., Held, A., Pfluger, B., Nuemann, K., Resch, G., Faber, T., Wiser, R., 2008 Assessment of the Effectiveness of Renewable Energy Support Schemes in the BRICS Countries. Fraunhofer Institute Systems and Innovation Research,

Karlsruhe/Energy Economics Group, Vienna University of Technology, Vienna/ Lawrence Berkeley National Laboratory, Berkeley.

Reed, W.R., Ye, H., 2011. Which panel data estimator should I use? Appl. Econ. 43, 985-1000. http://dx.doi.org/10.1080/00036840802600087.

Rogge, K.S., Hoffmann, V.H., 2010. The impact of the EU ETS on the sectoral innovation system for power generation technologies-findings for Germany. Energy Policy 38, 7639-7652.

Rogge, K.S., Schneider, M., Hoffmann, V.H., 2011. The innovation impact of the EU Emission Trading System-findings of company case studies in the German power sector. Ecol. Econ. 70, 513-523.

Schleich, J., 2009. Barriers to energy efficiency: a comparison across the German commercial and services sector. Ecol. Econ. 68, 2150-2159. http://dx.doi.org/ 10.1016/j.ecolecon.2009.02.008.

Smith, S., Swierzbinski, J., 2007. Assessing the performance of the UK Emissions Trading Scheme. Environ. Resour. Econ. 37.

Steinbach, A., 2013. Barriers and solutions for expansion of electricity grids-the German experience. Energy Policy 63, 224-229. http://dx.doi.org/10.1016/j. enpol.2013.08.073.

Szabó, S., Jäger-Waldau, A., 2008. More competition: Threat or chance for financing renewable electricity? Energy Policy 36, 1436-1447.

Tampakis, S., Tsantopoulos, G., Arabatzis, G., Rerras, I., 2013. Citizens' views on various forms of energy and their contribution to the environment. Renew. Sustain. Energy Rev. 20, 473-482. http://dx.doi.org/10.1016/j.rser.2012.12.027.

Upreti, B.R., 2004. Conflict over biomass energy development in the United Kingdom: some observations and lessons from England and Wales. Energy Policy 32, 785-800. http://dx.doi.org/10.1016/S0301-4215(02)00342-7.

Veugelers, R., 2011. Europe's clean technology investment challenge (Policy Contributions No. 561). Bruegel.

White, W., Lunnan, A., Nybakk, E., Kulisic, B., 2013. The role of governments in renewable energy: the importance of policy consistency. Biomass Bioenergy 57, 97-105. http://dx.doi.org/10.1016/j.biombioe.2012.12.035.

Wooldridge, J.M., Calhoun, J.W., Jung, B., Greber, S., Montgomery, R., 2009. Introductory Econometrics, 4th ed South-Western Cengage Learning, Mason, $\mathrm{OH}$.

Wüstenhagen, R., Menichetti, E., 2012. Strategic choices for renewable energy investment: conceptual framework and opportunities for further research. Energy Policy 40, 1-10. http://dx.doi.org/10.1016/j.enpol.2011.06.050.

Wüstenhagen, R., Wolsink, M., Bürer, M.J., 2007. Social acceptance of renewable energy innovation: An introduction to the concept. Energy Policy 35, 2683-2691. 